\title{
Panama: 2010 Article IV Consultation-Staff Report; Public Information Notice on the Executive Board Discussion; and Statement by the Executive Director for Panama
}

Under Article IV of the IMF's Articles of Agreement, the IMF holds bilateral discussions with members, usually every year. In the context of the 2010 Article IV consultation with Panama, the following documents have been released and are included in this package:

- The staff report for the 2010 Article IV consultation, prepared by a staff team of the IMF, following discussions that ended on May 27, 2010, with the officials of Panama on economic developments and policies. Based on information available at the time of these discussions, the staff report was completed on June 25, 2010. The views expressed in the staff report are those of the staff team and do not necessarily reflect the views of the Executive Board of the IMF.

- $\quad$ A Public Information Notice (PIN) summarizing the views of the Executive Board as expressed during its July 12, 2010 discussion of the staff report that concluded the Article IV consultation.

- A statement by the Executive Director for Panama.

The document listed below has been or will be separately released.

\section{Selected Issues Paper}

The policy of publication of staff reports and other documents allows for the deletion of market-sensitive information.

\author{
Copies of this report are available to the public from \\ International Monetary Fund • Publication Services \\ $70019^{\text {th }}$ Street, N.W. • Washington, D.C. 20431 \\ Telephone: (202) 623-7430 • Telefax: (202) 623-7201 \\ E-mail: publications@imf.org Internet: http://www.imf.org
}

\section{International Monetary Fund Washington, D.C.}





\title{
INTERNATIONAL MONETARY FUND
}

\author{
PANAMA
}

\section{Staff Report for the 2010 Article IV Consultation}

Prepared by the Staff Representatives for the 2010 Consultation with Panama

Approved by Miguel A. Savastano and Jan Kees Martijn

June 25,2010

- Context and recent developments. Panama weathered the global financial crisis well. While output growth slowed substantially in 2009, it remained positive and above the region's average. The banking system remained on a strong footing. The economy is rebounding strongly, supported by more favorable external conditions, and a large increase in public investment, notably from the Canal expansion project. Panama's credit rating was raised to investment grade in early 2010.

- Key policy recommendations:

○ A modest withdrawal of fiscal stimulus in 2010 would be broadly appropriate. Additional stimulus is not essential given the strength of the economic recovery.

- Adherence to the fiscal consolidation targets envisaged for the medium term is important. A rapid decline in public debt would create substantial additional room for countercyclical fiscal policy.

- The government's medium-term fiscal framework (MTFF) can be strengthened. In particular, the MTFF could spell out more fully the underlying macroeconomic framework and targets for key components of the nonfinancial public sector.

- Plans to broaden the financial system's regulatory perimeter are welcomed. Bringing all deposit-taking institutions under the supervision of the Superintendency of Banks would help limit risks to the financial system.

- The financial safety net can be strengthened. A formal safety net would further bolster financial stability and reduce costs from excessive bank liquidity holdings.

- Authorities' views. The authorities broadly concurred with the staff's recommendations on fiscal policy and the financial sector. They expressed concern, however, that a formal safety net would create moral hazard.

- Mission: The 2010 Article IV consultation discussions were held during May 17-27. The staff team comprised Lisandro Abrego (head), Juliana Araujo, Mario Dehesa, Kristin Magnusson Bernard (all WHD), and Torsten Wezel (MCM). The mission met with Minister of Finance, Alberto Vallarino; Superintendent of Banks, Alberto Diamond; other senior officials; and private sector representatives. 


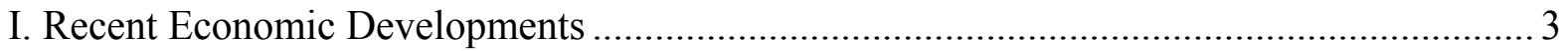

II. Macroeconomic Outlook and Risks .................................................................... 12

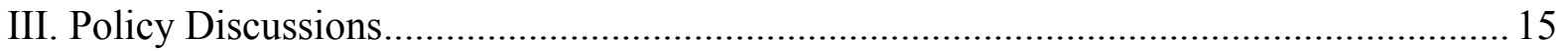

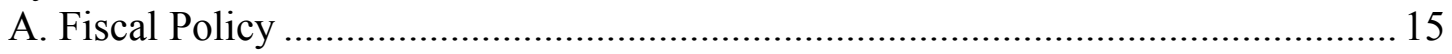

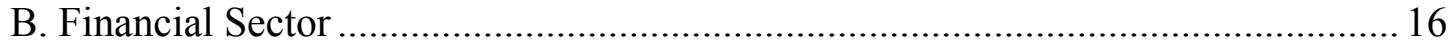

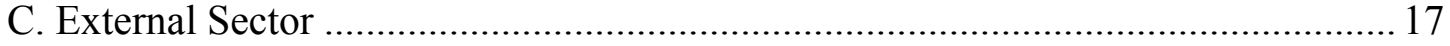

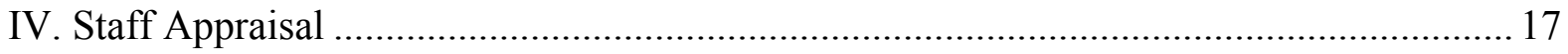

Figures

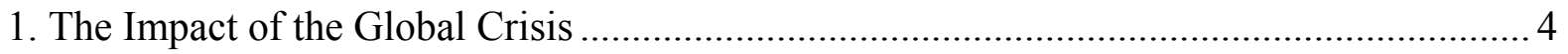

2. The Make-Up of the Recovery, 2009-10 ...................................................................... 5

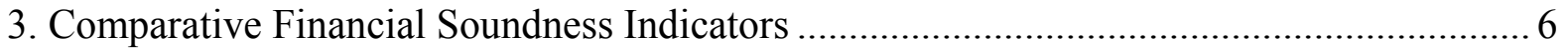

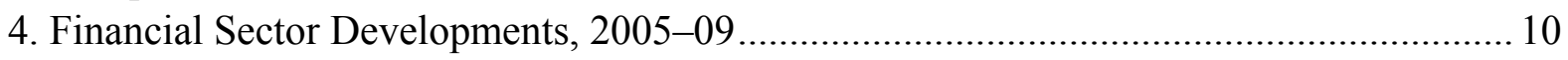

5. Public Debt Sustainability: Bound Tests.................................................................... 31

Tables

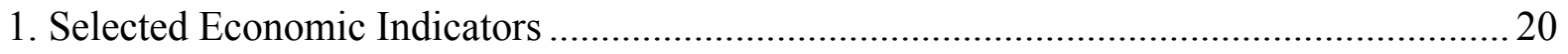

2. Summary of the Nonfinancial Public Sector .................................................................... 21

3. Summary Operations of the Central Government ....................................................... 22

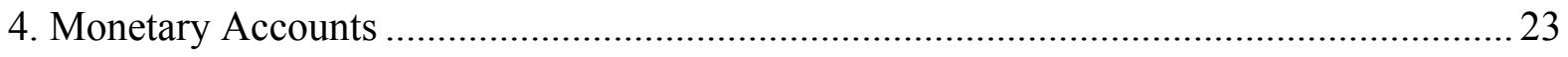

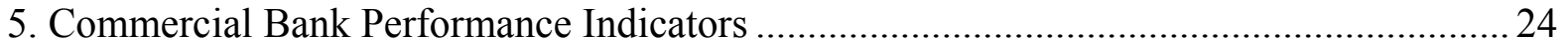

6. Medium-Term Macroeconomic Framework .................................................................. 25

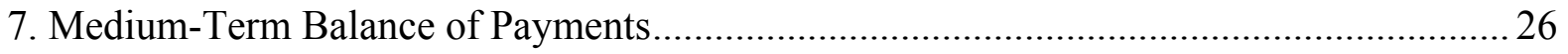

8. Debt of the Nonfinancial Public Sector......................................................................... 27

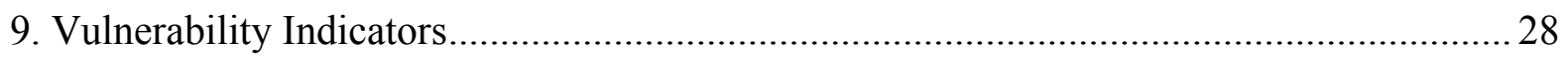

10. Public Sector Debt Sustainability Framework, 2006-15 ......................................... 29

Boxes

1. Performance of Domestic vs. Foreign Banks During the Crisis ...................................... 7

2. Monetary Conditions in Panama During the Global Crisis............................................. 9

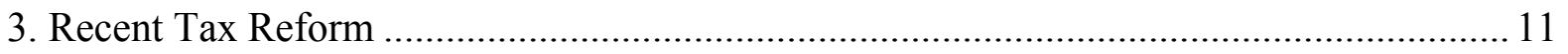

4. Potential Growth and Output Gap in Panama ........................................................... 13

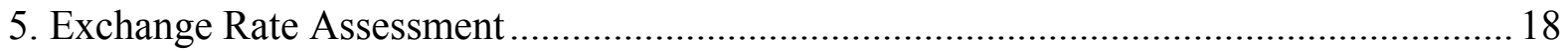

Annex

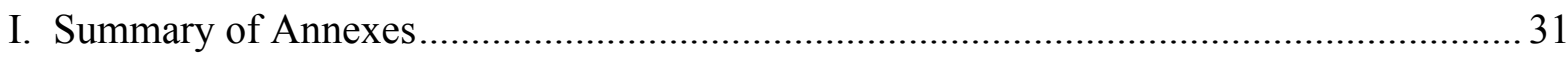




\section{RECENT DEVELOPMENTS}

\section{Panama faced the global financial crisis of 2008 from a strong position. Fiscal} consolidation and rapid economic growth during 2004-08 helped reduce public debt below 40 percent of GDP. Supported by tax and social security reforms, the fiscal policy framework was strengthened and became more resilient. Banks' loan portfolio had expanded only moderately during the high-growth years, and the system was on a strong footing and subject to a sound regulatory framework. In addition, when the global crisis struck, the ambitious seven-year Canal expansion project was already underway, providing timely support to economic activity.

\section{Economic growth slowed significantly in 2009, but remained positive and above the} region's average. Real GDP growth fell from $103 / 4$ percent in 2008 to $2 \frac{1}{2}$ percent in 2009 , driven by the global downturn and a slowdown in private construction, giving rise to a small negative output gap (Figure 1). Inflation declined to 2 percent $(63 / 4$ percent in 2008$)$, reflecting the unwinding of global supply shocks and the slowdown of domestic demand. Economic activity rebounded strongly in the last quarter of 2009 and the recovery has continued in the first quarter of 2010 (Figure 2). Driven mainly by higher oil and food prices, inflation has risen in

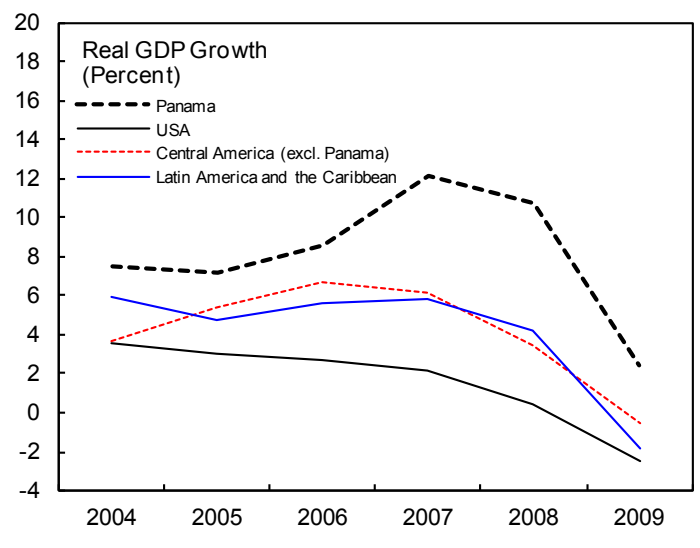
recent months, but remains low (about 3 percent in May, y/y).

3. The external current account improved markedly. Official estimates indicate that the current account was close to zero in 2009 (after posting a deficit of 11 1 $\frac{1}{2}$ percent in 2008), reflecting lower oil prices and very strong export receipts from the Colon Free Zone (CFZ). ${ }^{1}$ Trade outside the CFZ, however, declined significantly, as in the rest of the region. Foreign direct investment flows also fell, but remained high by historical standards and compared to the rest of the region; portfolio inflows to the banking sector also declined. Both trade and private capital flows began to rebound in late 2009 .

\section{Panama's large banking system weathered the global financial crisis well, reflecting a} prudent stance and strong supervision. Private domestic and foreign banks were impacted somewhat differently by the crisis (Box 1). However, financial soundness indicators remained solid in both groups, with low NPL ratios (1.4 percent overall in March 2010) and strong capital levels (Figure 3). As in the rest of the region, bank profits declined, but have started to recover. Recent

\footnotetext{
${ }^{1}$ Official estimates show that the value of net exports from the CFZ rose by 8 percentage points of GDP in 2009. Most of the increase is accounted for by a temporary surge in exports of medical products, related mainly to the A/H1N1 flu pandemic.
} 
Figure 1. Panama: Impact of the Global Crisis
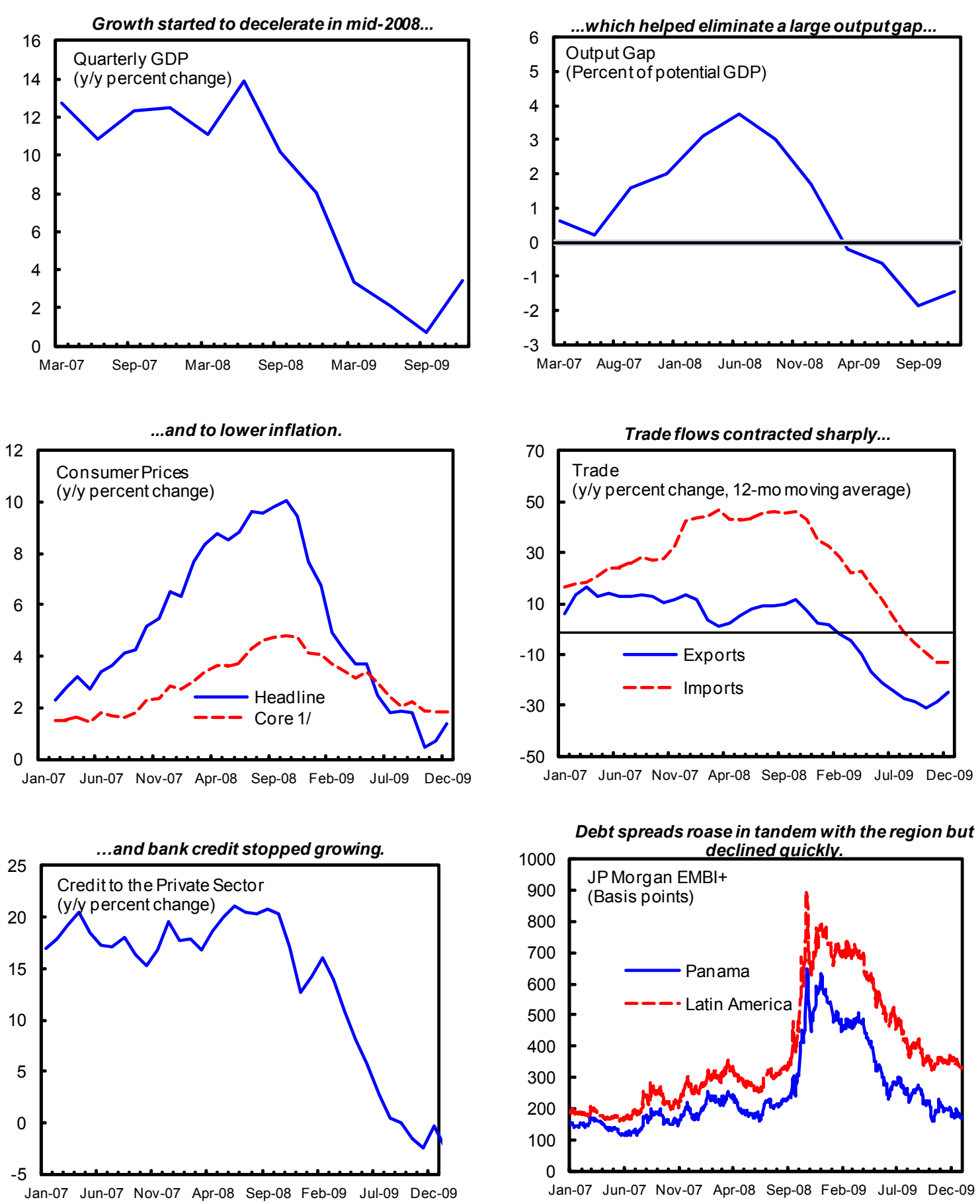

1/ Excludes food and fuel.

Sources: National Auth orities; Bloomberg; and Fund staff calculations. 
Figure 2. Panama: The Make-Up of the Recovery, 2009-10
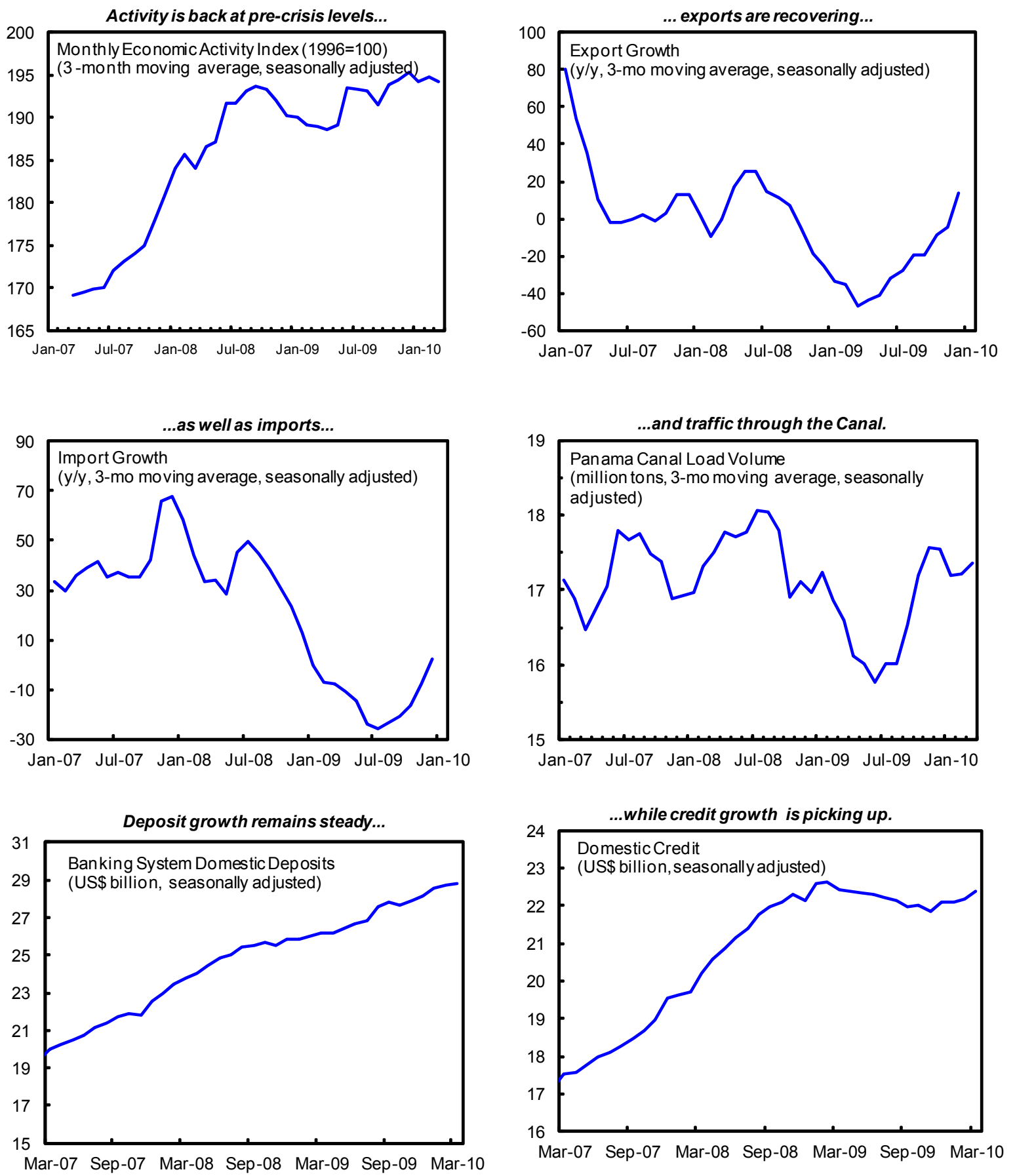

Sources: Haver Analytics; Bloomberg; EconData; National Authorities; and Fund staff calculations. 
Figure 3. Panama: Comparative Financial Soundness Indicators

Capital levels remain strong.
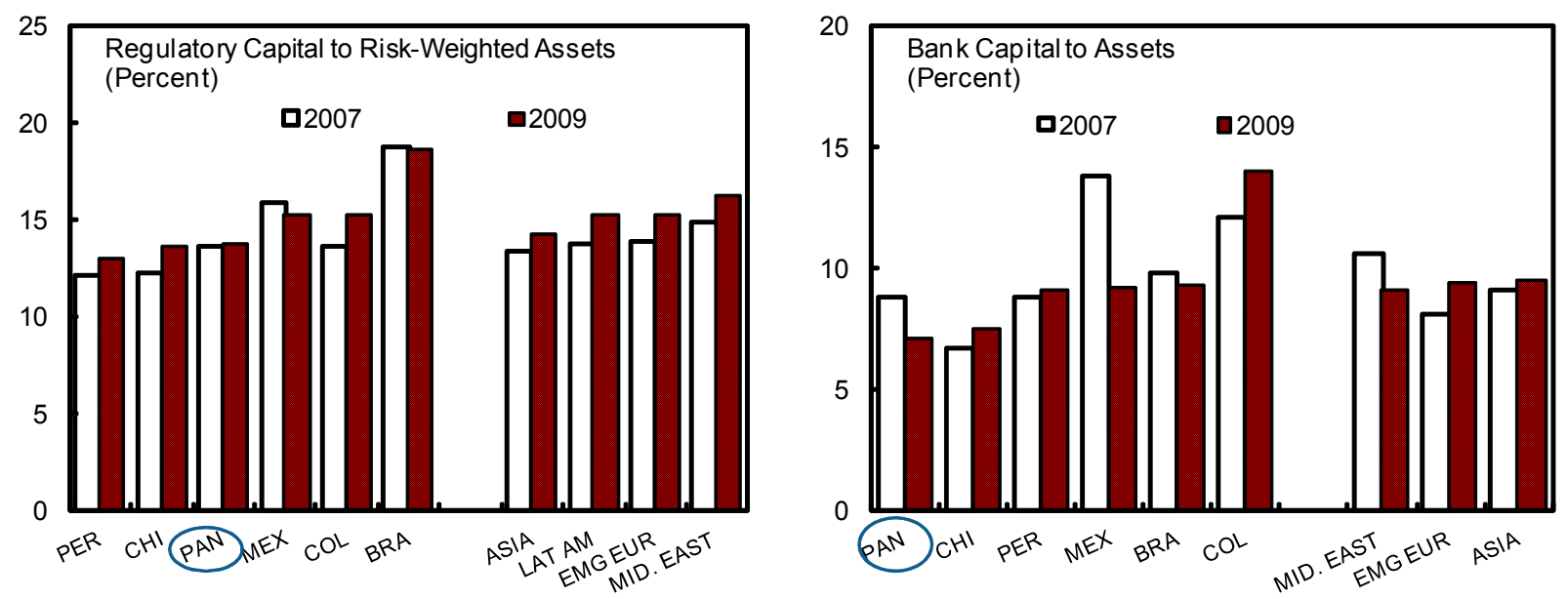

NPLs remain low, though provisions have declined.
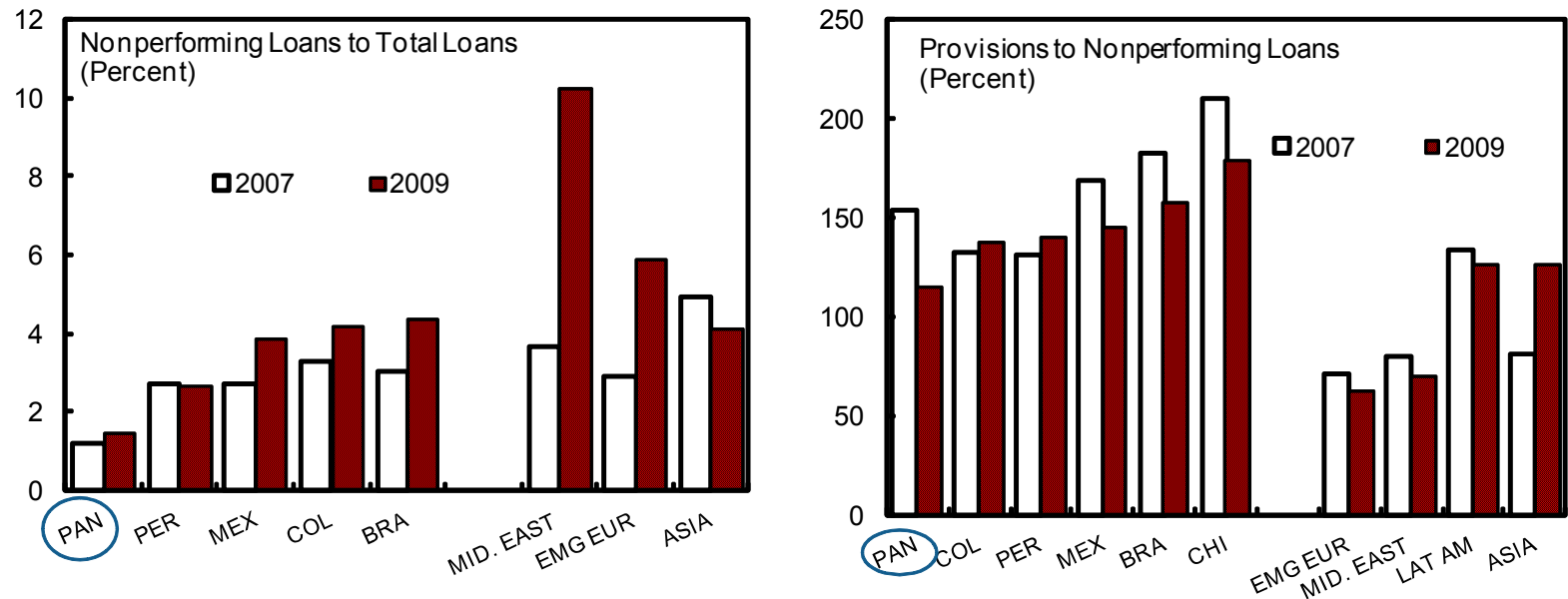

Profits are lower, as in the rest of the region.
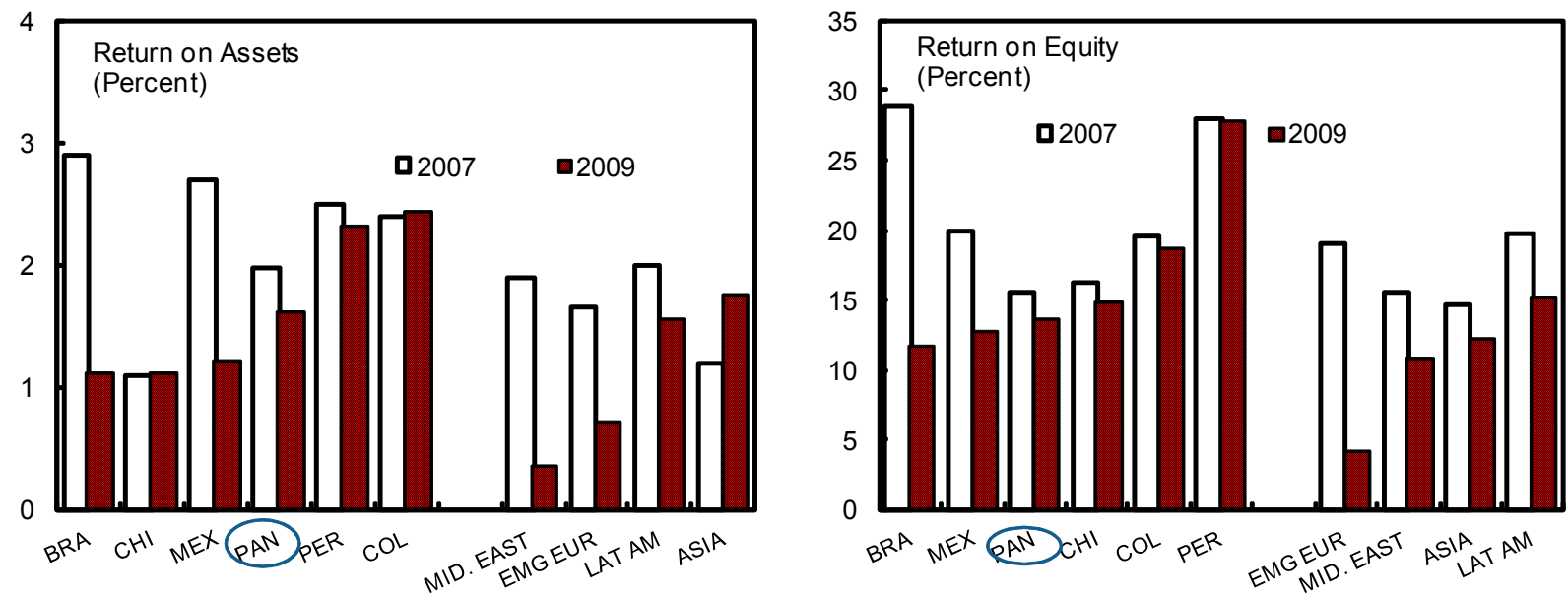

Sources: National Authorities; and Fund staff calculations. 
Box 1. Performance of Domestic vs. For eign Banks During the Crisis

While all banks in Panama were affected by the global financial crisis, private domestic and foreign banks fared differently on several counts. Loan quality and profitability of foreign banks were affected more severely than those of their domestic competitors. The NPL ratio declined in both groups of banks, aided by higher-than-usual write-offs. In general, foreign banks started recognizing delinquencies earlier than domestic banks, with their ratio of provisioning to loans peaking in 2008. Lower income from operations, mostly due to the weakness in loan origination, led to a drop in the return on assets of foreign banks in 2009, which now matches the lower but steady return of domestic banks.

Evolution of Key Financial Soundness Indicators, 2007-09

(In percent, unless otherwise indicated)

\begin{tabular}{|l|l|ccc|}
\hline Indicator & Type of Bank & 2007 & 2008 & 2009 \\
\hline Share of System Assets 1/2/ & Private Domestic Banks & 29.3 & 29.5 & 31.9 \\
& Foreign Banks & 57.6 & 57.4 & 53.9 \\
\hline Return on Assets & Private Domestic Banks & 1.5 & 1.6 & 1.5 \\
& Foreign Banks & 2.1 & 2.7 & 1.4 \\
\hline NPL Ratio 1/ & Private Domestic Banks & 0.8 & 1.0 & 0.9 \\
& Foreign Banks & 1.5 & 1.7 & 1.5 \\
\hline Provisioning/Total Loans & Private Domestic Banks & 0.3 & 0.5 & 0.6 \\
& Foreign Banks & 1.1 & 1.0 & 0.8 \\
\hline Liquidity Ratio 1/ 3/ & Private Domestic Banks & 33.7 & 32.3 & 37.4 \\
& Foreign Banks & 36.6 & 40.0 & 39.9 \\
\hline Credit Growth & Private Domestic Banks & 22.2 & 14.6 & 1.9 \\
& Foreign Banks & 20.0 & 11.0 & -2.0 \\
\hline Capital Adequacy Ratio 1/ & Private Domestic Banks & 15.2 & 15.7 & 17.1 \\
& Foreign Banks & 12.4 & 12.2 & 14.2 \\
\hline Flow of External Funding & Private Domestic Banks & 132 & 239 & -203 \\
(In US\$ million) 4/ & Foreign Banks & 2,118 & 3,141 & -686 \\
\hline Flow of Domestic Funding & Private Domestic Banks & 1,175 & 2,130 & 1,557 \\
(In US\$ million) 4/ & Foreign Banks & 3,202 & 1,284 & -59 \\
\hline
\end{tabular}

Source: Superintendency of Banks of Panama .

$1 /$ Year-end figures.

2/ Shares do not add up to 100 because public banks are excluded.

3/ Sum of liquid assets and traded securities in percent of deposits.

4/ Excludes the effects of the foreign acquisition of a domestic bank in 2007 and 2009.

In late 2008, many foreign banks adopted a more cautious approach to lending. Credit by foreign banks declined by 2 percent in 2009 , while credit by private domestic banks rose by a similar magnitude. The credit contraction at foreign banks seems to also reflect lower external funding, notably from reduced credit lines. By contrast, domestic banks easily compensated the loss of external funding through continued high access to domestic sources.

Liquidity increased in both groups during the crisis. Foreign banks, however, started to increase their liquidity holdings earlier than domestic banks. 
turmoil in European sovereign debt markets has not had any discernible impact on the banking system, in line with the relatively weak financial linkages with that region. Pro-active bank supervision contributed to maintaining the system on a strong footing. The Superintendency of Banks (SBP) stepped up its monitoring activities during the crisis and, since 2008, strongly and successfully encouraged banks to tighten lending standards in sectors that had been growing very strongly. These efforts were supplemented, in early 2009, by the creation of the financial stimulus program (FSP), aimed at providing resources to banks for on-lending to the private sector. In the event, however, banks made little use of those resources, mainly because their liquidity remained ample and the cost of FSP resources was relatively high.

5. Growth of bank credit decelerated significantly in 2009, but has begun to pick up. The slowdown reflected both weaker domestic demand and tighter lending standards, and was more pronounced for foreign banks (Box 1). Deposit growth remained solid, contributing to the buildup of very high levels of liquidity. Growth of bank lending began to recover in the first quarter of 2010, although at a gradual pace. The lax monetary conditions in the U. S. had some effect on Panama's monetary conditions - although with a lag-helping support economic activity during the global crisis (Box 2).

\section{6. $\quad$ Fiscal policy helped support domestic demand}

(Figure 4). The previous government took advantage of Panama's relatively strong fiscal position, and, with support from congress and the incoming administration, ${ }^{2}$ raised the deficit ceiling in the social and fiscal responsibility law (SFRL) to maintain an expansionary fiscal stance during 2009. ${ }^{3}$ In the event, the overall fiscal deficit was substantially below the modified SFRL ceiling, but the fiscal stimulus (in cyclically-adjusted terms and excluding the Panama Canal Authority) was in the order of $3 / 4$ percentage points of GDP.

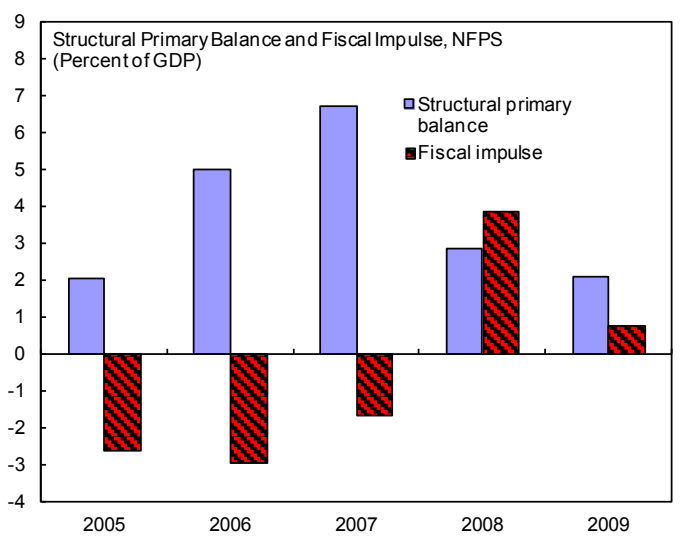

\section{In its first year in office, the new government has put in place two substantive tax reforms}

(Box 3). The reforms seek to raise tax revenue collections and improve the efficiency of the tax system, with the additional revenue to be used to finance higher capital spending. The first reform, approved in September 2009, broadened the tax base and raised dividend taxation, and is expected to yield 1 1/4 percent of GDP in revenue. The second reform, passed last March, raised the value-added tax, lowered personal and corporate income tax rates, and eliminated loopholes; altogether, the

${ }^{2}$ Presidential elections were held in May 2009 and President Martinelli (the candidate from the opposition) took office in July.

${ }^{3}$ Specifically, in June 2009 the SFRL deficit ceiling was raised from 1 percent of GDP to $2 \frac{1}{2}$ percent of GDP during times of global and domestic recessions. The modification allows a gradual return to the original deficit ceiling of 1 percent of GDP after four years. 


\section{Box 2. Monetary Conditions in Panama During the Global Crisis}

As a fully-dollarized economy, Panama cannot conduct an independent monetary policy. However, in principle, changes in monetary conditions in the U.S. should be transmitted to Panama and affect the domestic economy. Depending on the degree of business-cycle synchronization between the two economies, the monetary stance imported by Panama from the U.S. may or may not be appropriate for its economy.

Changes in nominal lending rates in Panama tend to follow those in the U.S. However, as shown in the chart, it takes several quarters for interest rate changes in the U.S. to be transmitted to Panama. Moreover, the relation seems to be asymmetrical. While the increases in rates before the global crisis were of similar magnitudes in both countries, the decline in rates was more modest in Panama following the crisis. One possible explanation for the asymmetry is that the lack of a lender of last resort induced

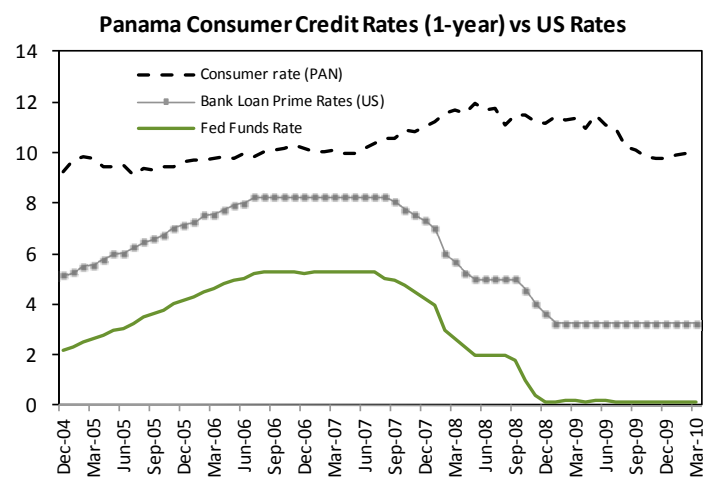
Panamanian banks to adopt relatively more conservative lending standards during the financial crisis. Sustained relatively high deposit rates also likely limited the scope for decreasing lending rates.

Given lags in real business cycles and in the transmission of interest rate changes, monetary conditions in Panama were broadly appropriate during the global crisis. To gauge the appropriateness of de facto monetary conditions, we present nominal lending rates relative to a baseline level when the monetary policy stance is neutral, i.e. when the economy is operating at full potential. ${ }^{1}$ During the crisis, monetary conditions in Panama began to ease when the output gap peaked in mid-2008, and continued on an easing trend as the gap closed and eventually turned negative in 2009. This suggests a broadly appropriate de facto monetary stance, especially since changes in interest rates affect the real

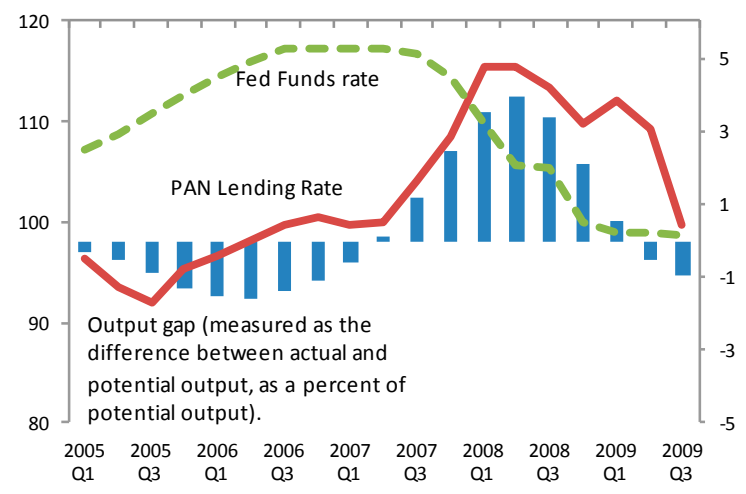
economy only with a lag. In contrast, the tightening of monetary conditions in Panama in late 2005 seems, in retrospective, to have been somewhat premature.

\footnotetext{
${ }^{1}$ The real interest rate is arguably the more important variable for economic activity. However, the focus is here on nominal rates, since the relationship between these across countries is independent of inflation. The latter affected the two economies differently in recent years, because of the impact of commodity price inflation.
} 
Figure 4. Panama: Fiscal Sector Developments, 2005-09
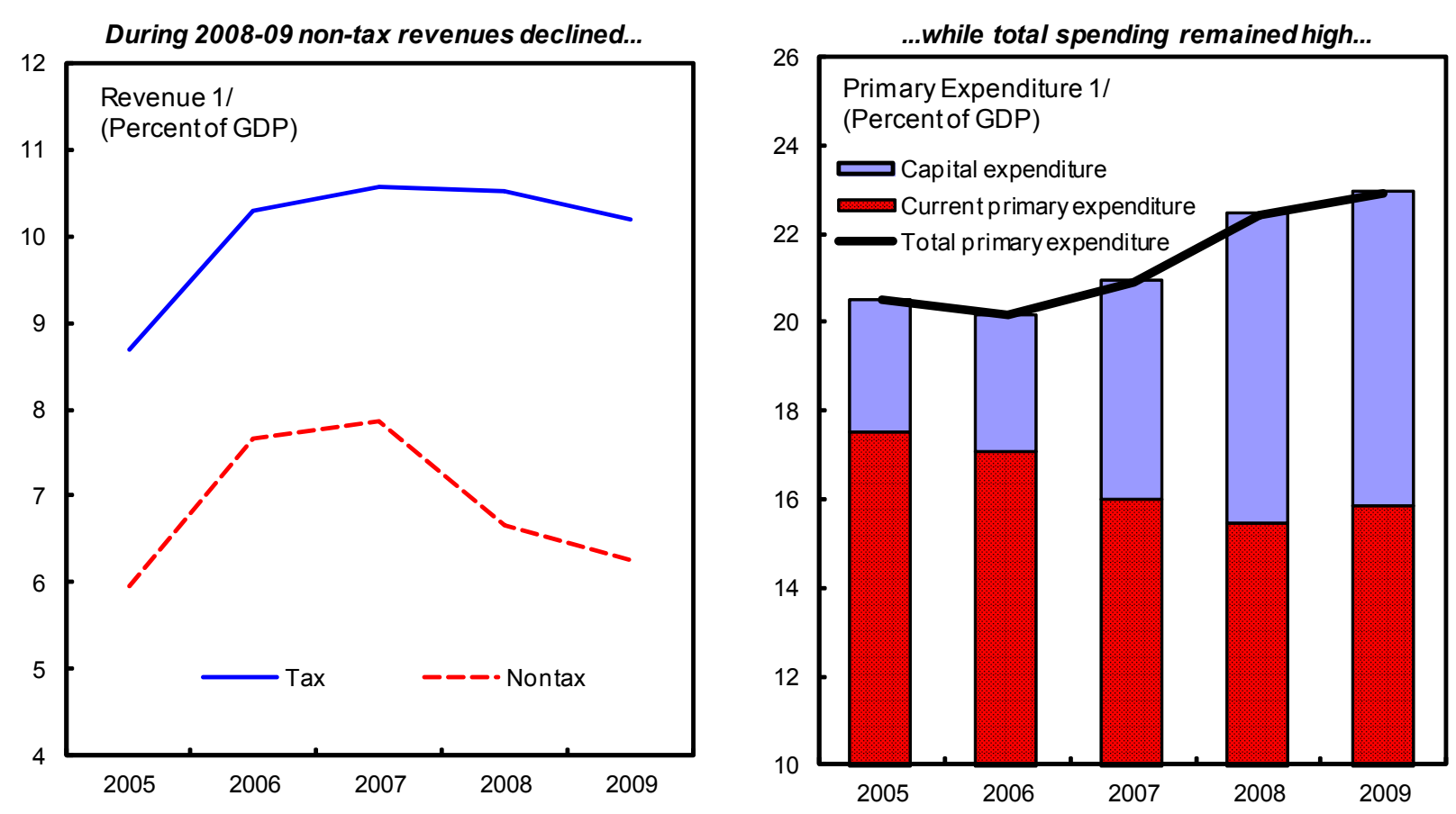

...resulting in a positive impulse.
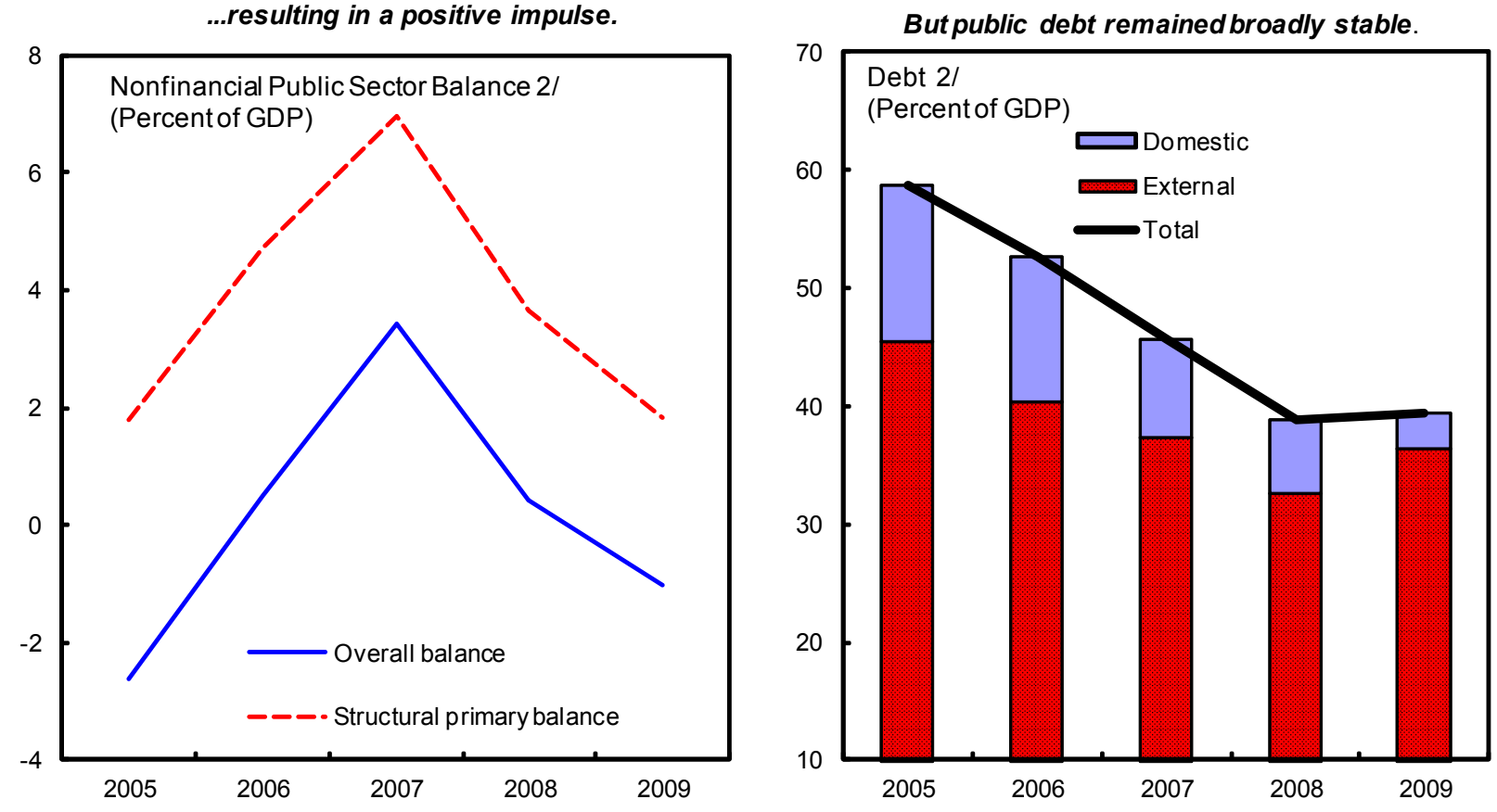

1/ Data refers to the Central Government.

2/ Excludes Panama Canal Authority

Sources: National Authorities; and Fund staff calculations. 


\section{Box 3. Recent Tax Reform}

In its first year in office, the government of President Martinelli has enacted two far-reaching tax reforms. With these reforms, Panama's tax system has increased its reliance on indirect taxes, reduced income tax rates while broadening the tax base, improved dividend taxation, and is modernizing its tax administration. The reforms are expected to increase government revenue by $2 \frac{1}{4}$ percent of GDP on a permanent basis.

The first tax reform, approved in September 2009, broadened the tax base, changed tax rates on specific sectors, increased license fees and enhanced tax administration. The changes made the Colón Free Zone, casinos, maritime transportation, and oil trade subject to a more comprehensive corporate and dividend taxation treatment, while taxing profits from some foreign operations. In addition, the reform levied taxes on real estate transactions-including capital gains on the sale of property-and brought bank commissions under VAT coverage.
Table 1 : September 2009 tax reform projected revenue ( In percent of GDP)

\begin{tabular}{ll}
\hline Corporate and dividends taxation & 0.3 \\
Property taxation reform & 0.2 \\
Increased license fees & 0.2 \\
VAT to bank commissions & 0.2 \\
Others & 0.3 \\
Total & 1.2 \\
\hline
\end{tabular}

Source: Authorities' estimates.

The second tax reform lowered personal and corporate income tax rates, raised the VAT rate, and made additional improvements to tax administration. The rates of personal income tax (PIT) were lowered from 20-27 percent to 15-25 percent and the exempted income threshold level was raised from 1.1 to 1.4 times income per capita. The rate of the corporate income tax (CIT) was lowered from 30 percent to 25 percent over two years, and over 4 years for some sectors (telecommunications, banking, electricity, insurance and casinos). Most personal expenditure deductions were eliminated and the corporate expenditure calculation

Table 2 : March 2010 tax reform package projected revenue

\begin{tabular}{lrr}
\hline & Percent of GDP \\
\cline { 2 - 3 } & 2010 & 2011 \\
\hline Income tax reform & & \\
& & \\
& -0.4 & -0.4 \\
PIT tax rate reduction to 15-25 percent from 20-27 percent & -0.1 & -0.1 \\
Higher exempted income threshold & 0.3 & 0.3 \\
Personal deductions are eliminated / minimized & -0.1 & -0.2 \\
CIT reduction to 25 percent & 0.3 & 0.3 \\
New method to calculate expense deductions & 0.1 & 0.1 \\
Other & & \\
Consumption taxation & 0.4 & 0.8 \\
VAT rate increase from 5 to 7 percent & 0.1 & 0.2 \\
VAT coverage net expansion & 0.1 & 0.1 \\
Other & 0.6 & 1.0 \\
Total & & \\
\hline
\end{tabular}

Source: Authorities' estimates. method was modified, notably for the financial sector. The minimum alternative tax rate was also lowered while the standard rate of the VAT was increased from 5 percent to 7 percent. Operational and financial autonomy was granted to the tax administration unit, and a specialized tax court was created.

Income tax rates in Panama are now below international levels. The PIT rate is slightly below the regional average and substantially lower than the OECD average. The top CIT rate is also somewhat lower than the regional average and broadly similar to the OECD average. 
changes are expected to increase revenue by 1 percent of GDP.

8. Panama's sovereign credit rating was raised to investment grade. Earlier this year, the three main credit-rating agencies raised Panama's sovereign debt classification by one notch to BBB-, citing the strengthening of the public finances, prospects for further declines in public debt, and a very favorable growth outlook.

\section{The authorities have made substantial progress towards Panama's removal from the}

OECD grey list of tax havens. In the last year, the government has concluded negotiations for 9 of the 12 double taxation treaties required for removal from the grey list. The authorities expect to complete the remaining agreements before end-2010, and adopt the changes to domestic legislation needed to implement them.

\section{MACROECONOMIC OUTLOOK AND RISKS}

10. Economic growth is expected to pick up rapidly: Staff projects real GDP growth of 4.8 percent in 2010, supported by an improved global environment and a large increase in public investment, notably from the Canal expansion project. Growth is projected to rise to $6 \frac{1}{2}$ percent by 2012, as the Canal expansion works peak and private demand recovers fully. The recent upgrade to investment grade is expected to have favorable effects on confidence and private investment. ${ }^{4}$ Output growth is then expected to hover around 6 percent, broadly in line with current potential growth estimates by staff (estimates that are somewhat lower than those prior to the global crisis (Box 4)). Completion of the expansion of the Canal in 2014 is expected to have a permanent positive effect on potential growth.

\begin{tabular}{|c|c|c|c|c|c|c|c|c|}
\hline \multicolumn{9}{|c|}{ Text Table 1. Panama: Medium-Term Outlook } \\
\hline & \multicolumn{3}{|c|}{ Prel. } & \multicolumn{4}{|c|}{ Proj. } & \multirow[b]{2}{*}{2015} \\
\hline & 2008 & 2009 & 2010 & 2011 & 2012 & 2013 & 2014 & \\
\hline \multicolumn{9}{|c|}{ (Annual percent change) } \\
\hline \multicolumn{9}{|l|}{ Production and prices } \\
\hline Real GDP & 10.7 & 2.4 & 4.8 & 6.3 & 6.5 & 6.2 & 6.2 & 6.5 \\
\hline Consumer price index (end of year) & 6.8 & 1.9 & 3.0 & 2.7 & 2.5 & 2.5 & 2.5 & 2.5 \\
\hline \multicolumn{9}{|c|}{ (In percent of GDP) } \\
\hline \multicolumn{9}{|l|}{ Public finances } \\
\hline NFPS primary balance (excl. PCA) & 3.5 & 1.8 & 2.0 & 1.7 & 2.0 & 2.3 & 2.3 & 2.5 \\
\hline NFPS overall balance (excl. PCA) & 0.4 & -1.0 & -0.9 & -0.9 & -0.5 & -0.1 & 0.3 & 0.5 \\
\hline NFPS structural primary balance (excl. PCA) & 2.8 & 2.1 & 2.4 & 2.0 & 2.3 & 2.6 & 2.5 & 2.5 \\
\hline NFPS overall balance & 2.5 & -0.5 & -2.0 & -2.0 & -2.1 & -1.1 & 0.2 & 1.1 \\
\hline Total public debt $1 /$ & 38.8 & 39.4 & 40.4 & 38.8 & 37.4 & 35.2 & 31.9 & 28.5 \\
\hline \multicolumn{9}{|l|}{ External sector } \\
\hline Current account & -11.6 & 0.0 & -7.9 & -8.0 & -8.5 & -7.7 & -5.9 & -4.5 \\
\hline Foreign direct investment & 10.4 & 7.2 & 7.7 & 7.9 & 8.0 & 8.0 & 8.1 & 8.1 \\
\hline
\end{tabular}

\footnotetext{
${ }^{4}$ Chapter 1 of the accompanying Selected Issues Paper discusses the benefits that accrue from having investment grade.
} 


\section{Box 4. Potential Growth and Output Gap in Panama}

The evidence suggests that Panama's potential growth increased in recent years. Results from three different methodologies to calculate potential growth suggest a significant difference in Panama's potential growth rates in the period 2003-09 compared to earlier years. ${ }^{1}$ On average, Panama's potential GDP growth seems to have increased from 33/4 percent per year during 1996-2002 to about 71/2 per year in recent years.

Statistical tests identify 2003 as a structural break point in the GDP time series. The recent acceleration of potential growth reflects to a great extent a large increase (6 percentage points of GDP during 2003-08) in domestic investment, with strong contributions from public and foreign direct investment. Productivity growth is also estimated to have risen, although more modestly. At the sectoral level, the higher growth appears to have been driven by the outwardly-oriented services sector (the Canal and various activities linked to it), which benefited greatly from the strong surge in global growth and trade during 2003-07.

\section{Output gap measures derived from these estimates suggest that the excess demand pressures of 2008 abated in 2009. The} estimated output gap reached $3 \frac{1}{2}$ percent of potential GDP in 2008, but disappeared in early 2009 as the effects of the global crisis reached Panama. For 2009 as a whole, the output gap was about -1 percent of GDP.

\section{Lower global trend growth is likely to have} an adverse effect on Panama's potential

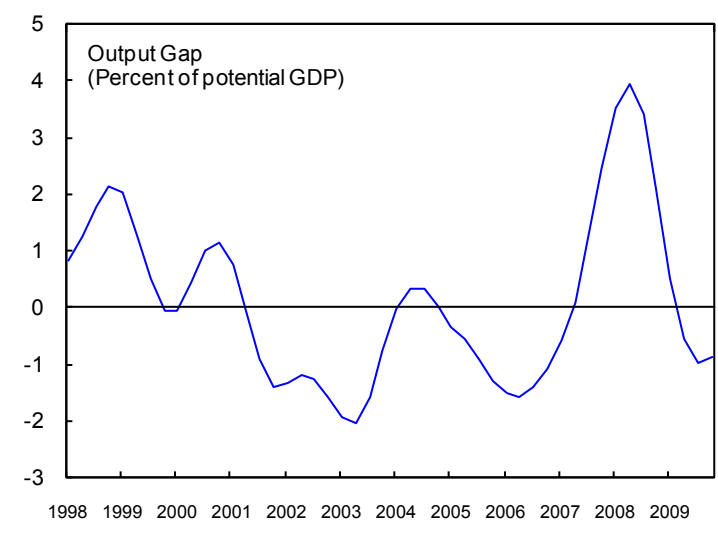

Panama. Estimates of Potential Growth, percent per year

\begin{tabular}{lccc} 
& 1996Q1-2009Q4 & 1996Q1-2003Q1 & 2003Q1-2009Q4 \\
\cline { 2 - 4 } Linear detrending & 5.75 & 3.69 & 7.77 \\
Hodrick and Prescott & 5.85 & 3.98 & 7.71 \\
Baxter and King & 5.81 & 3.37 & 7.44 \\
Christiano and Fitzgerald & 5.82 & 3.48 & 7.34 \\
Beveridge-Nelson & 5.82 & 3.97 & 7.55 \\
Average & 5.81 & 3.70 & 7.56 \\
\hline
\end{tabular}

Linear detrending

Hodrick and Prescott

Christiano and Fitzgerald

Beveridge-Nelson

Average

growth. While there is considerable

uncertainty about magnitudes, most baseline scenarios assume global potential growth to be lower in the coming years. Estimates from a multivariate analysis suggest that a fall in global growth of 1 percentage point would tend to decrease Panama's growth by a similar magnitude.

\footnotetext{
${ }^{1}$ The univariate techniques used to calculate permanent output were: (i) piece-wise linear de-trending; (ii) filters that isolate high-frequency from low-frequency components (HP-filter, the Baxter and King filter, and the Christiano and Fitzgerald filter); and (iii) the Beveridge and Nelson decomposition. These techniques were applied to quarterly data for 1996-2009, and to staff projections for $2010-11$ to correct for end-of-period bias.
} 


\section{The external current account is projected to weaken, while inflation would remain}

subdued. The current account deficit is projected to peak at $81 / 2$ percent of GDP in 2012 with the Canal works. Thereafter, as the project winds down and the expanded Canal becomes operational, the deficit is expected to decline significantly. With a very large proportion of spending from the project falling on imports, domestic demand pressures are expected to remain contained. Inflation is projected to rise temporarily in 2010 - in line with global inflation and higher oil prices - but is expected to stabilize thereafter at $2 \frac{1}{2}$ percent per year.

12. The fiscal deficit in 2010 is projected to remain well below the SFRL ceiling. The deficit target in the 2010 budget (1.9 percent of GDP, excluding the Panama Canal Authority) is likely to be overperformed by a significant margin. Revenues are projected to grow strongly following the recent tax reforms, while the ambitious capital spending plans contained in the budget are not likely to be completed due to implementation constraints. Staff projects an overall fiscal deficit of 0.9 percent of GDP for 2010, broadly unchanged from 2009. ${ }^{5}$ For 2011, the authorities' newly-adopted medium-term fiscal framework (MTFF) envisages an overall deficit of $1 \frac{1}{4}$ percent of GDP, consistent with higher capital spending. Fiscal consolidation is expected to continue over the medium term at a faster pace than contemplated in the SFRL, resulting in a decline of public debt below 30 percent of GDP by 2015 .

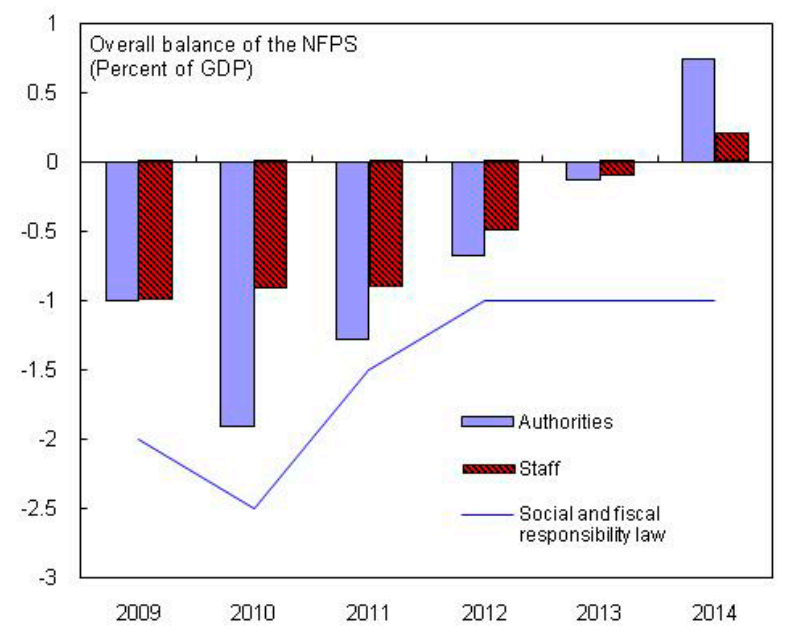

13. Risks to the outlook are broadly balanced. Downside risks to growth stem from a less favorable external environment or a more sluggish recovery of credit. Domestic growth is particularly sensitive to changes in global economic conditions. ${ }^{6}$ Upside risks arise from stronger private (domestic and foreign) investment, on account of positive spillovers from higher public expenditure on infrastructure, as well as from the favorable effects of the upgrade in the sovereign credit rating. On the fiscal side, revenue could turn out higher than projected, given ongoing efforts to strengthen tax administration.

\footnotetext{
${ }^{5}$ The SFRL deficit ceiling for 2010 is $2 \frac{1}{2}$ percent of GDP. The 2009 SFRL reform contained a carry-over provision stating that if the fiscal outturn is below the deficit ceiling in the first year of the recession, the ceiling for the following year may increase by up to 0.5 percent of GDP.

${ }^{6}$ Staff's empirical analysis finds a strong relationship between U.S. and domestic growth, and a more moderate effect on growth from changes in domestic credit (see Chapter 2 of the Selected Issues Paper).
} 


\section{Policy Discussions}

\section{A. Fiscal Policy}

14. There was agreement that a modest withdrawal of fiscal stimulus in 2010 was appropriate. Staff projects a slight strengthening of the primary balance in cyclically-adjusted terms in 2010 (Text Table 1). Although there is still scope for a small positive impulse, given the negative output gap and good access to financing, implementation constraints to investment are likely to be binding. Given the strength of the recovery, it was agreed that the additional impulse was not essential and the projected fiscal stance was broadly appropriate. There was also agreement that maintaining a low overall deficit would help further strengthen fiscal credibility.

15. Staff supported the authorities' recent tax reforms. The reforms bolster the credibility of Panama's fiscal framework, will allow higher levels of capital spending, and are economically sound, including by shifting from income to consumption taxation. Staff supported the authorities' ongoing efforts to strengthen tax administration, and encouraged them to take similar steps in the area of customs. The authorities expressed an interest in receiving Fund technical assistance in both areas.

\begin{tabular}{|lrr|}
\hline \multicolumn{3}{|c|}{ Text Table 2. Corporate and Personal Income Tax Rates } \\
Top Tax Rates for OECD Countries, Latin America and Central America 2008 \\
\hline \multicolumn{2}{|c|}{ CIT } & PIT \\
\hline Panama 1/ & 25.0 & 25.0 \\
Latin America Average 2/ & 27.5 & 27.7 \\
Central America Average 2/ & 28.5 & 27.7 \\
OECD average & 24.5 & 36.7 \\
\hline Sources: www.bus.umich.edu/OTPR/otpr/OTPRdataV3.asp (The World Tax Database of the University of & \\
Michigan); KPMG (2008) database; Summer: (2008) PriceWaterhouseCoopers and IBFD (2008). & \\
1/ After the March 2010 tax reform at end of 4 year adjustment period. & \\
2/ Excludes Panama,. & \\
\hline
\end{tabular}

16. The fiscal consolidation envisaged over the medium term is ambitious but feasible. The decline in public debt targeted in the MTFF would provide substantial additional scope for adopting a countercyclical fiscal stance. The staff noted that, given assumptions on revenue growth and economic growth, the MTFF targets seemed conservative. To bolster fiscal credibility further, staff advised the authorities to adhere to the MTFF targets and allocate any overperformance to a faster reduction of public debt.

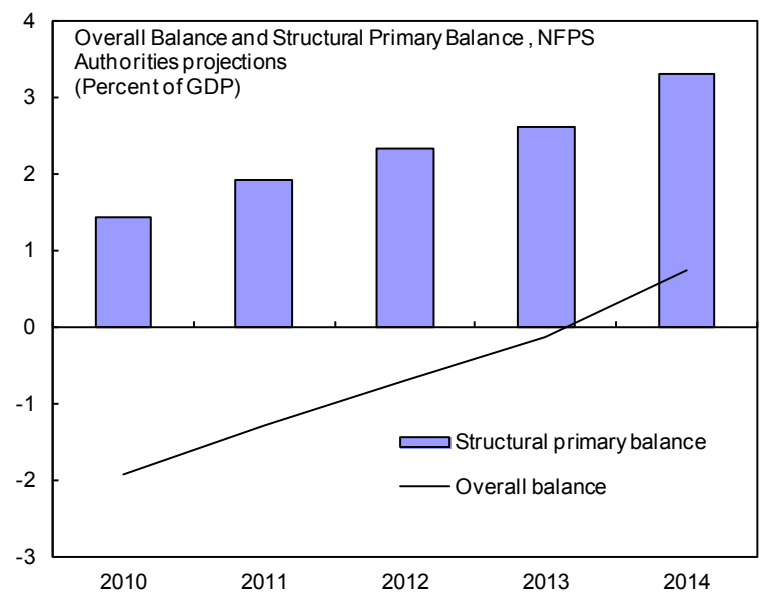

17. Staff encouraged the authorities to strengthen their MTFF. In particular, it recommended that the MTFF spells out in more detail the underlying macroeconomic framework and incorporates explicitly the key components of the nonfinancial public sector, including the social security system. 
The MTFF would also benefit from quantification and discussion of tax expenditures and a more thorough discussion of contingent liabilities. The authorities noted that they are working on enhancing the framework in some of these aspects, including by quantifying tax expenditures more comprehensively and including them in budget documents.

18. Staff welcomed the government's plans to increase infrastructure investment and restrain current spending. The authorities expect that higher public investment will help boost private-sector led growth. The mission noted the importance of phasing in carefully the additional spending planned for the outer years of the MTFF to ensure consistency with SFRL requirements, avoid excessive demand pressures, and ensure an efficient execution. Staff supported the authorities' ongoing efforts to put in place a legal framework for public-private partnerships to help support their investment program.

\section{B. Financial Sector}

\section{It was agreed that Panama's banking system showed strong resilience during the global}

financial crisis. The on-shore and off-shore segments of the system managed to preserve strong financial soundness indicators. In the case of the on-shore segment, a strong regulatory framework and banks' own conservative practices were important factors supporting such resilience. Looking ahead, stress tests conducted by the mission showed that capital levels in the banking system would remain adequate under sizeable shocks to economic activity and thus asset quality.

20. Staff noted that the slowdown in the construction sector had not had a significant impact on banks' balance sheets. Following a period of rapid expansion, the construction sector slowed down sharply in 2009 and the prices of some properties fell. The effects on banks' balance sheets were, however, negligible. Banks' decision to effectively limit loan-to-value ratios and set high presale requirements played a key role in containing exposure to the sector and in protecting their balance sheets. It was agreed, however, that remaining exposure to the sector warrants close monitoring.

\section{The mission encouraged the authorities to move forward with plans for the gradual} introduction of risk-based supervision. Staff and the authorities agreed that this step would help further enhance bank monitoring. The mission noted that risk-based supervision would be suitable for Panama, given the special features of its banking sector (e.g., substantial banks' cross-border linkages, credit concentration, and relatively high indebtedness of the private sector). The authorities have begun taking some preparatory steps, including improved auditing.

22. Staff supported plans to broaden the financial sector regulation perimeter. Some nonbank deposit-taking institutions (e. g., cooperatives) are currently not regulated by the Superintendency of Banks (SBP). Although the sector is small relative to the banking system and does not pose systemic risk, it was agreed that bringing all deposit-taking institutions under the umbrella of the SBP was a good practice which would limit risks going forward. The mission also welcomed the authorities' preparations to introduce Basel II regulatory requirements, as well as their plans to strengthen the 
regulatory framework for pensions and the insurance sector and to enhance the governance structure of the securities commission.

\section{The authorities concurred with the staff recommendation to explore the possibility of} establishing a formal safety net. There was agreement that the current arrangement under which banks self-insure against shocks by holding liquid assets had worked well, but had non-negligible costs. The authorities expressed concern, however, that a formal safety net would create moral hazard. Staff argued that a formal safety net could be designed to contain moral hazard while reducing individual bank liquidity needs, with positive effects on the supply of credit and interest rates. Staff also suggested exploring the possibility of establishing a limited insurance scheme for deposits at on-shore banks, financed with risk-based bank contributions. ${ }^{7}$ The scheme could cover a small fraction of total deposits, but nonetheless insure the vast majority of the system's accounts. The authorities also indicated that they would like to explore possible arrangements for emergency liquidity support. They expressed interest in receiving Fund technical assistance in these areas.

\section{External Sector}

24. The real exchange rate is in line with fundamentals (Box 5). Panama's real effective exchange rate remained broadly unchanged in 2009, with the strengthening of the U.S. dollar offset by lower domestic inflation. The mission's estimates for 2009-which are based on a countryspecific model of the equilibrium exchange rate and the macro-balance approach — point to a very small (less than 5 percent) overvaluation of Panama's real exchange rate.

\section{Efforts to furthe strengthen trade links with the rest of the world have continued. In May} 2010, Panama signed free trade agreements (FTAs) with Canada and the European Union, while negotiations on a deal with Colombia are ongoing. The agreement with the U. S. (concluded in mid2007), however, is awaiting approval by the U. S. Congress. The authorities expect that the implementation of FTAs will provide solid support to economic growth over the medium term by improving access to key markets and strengthening the competitiveness of the domestic economy.

\section{Staff Appraisal}

26. Supported by strong fundamentals, Panama weathered the global financial crisis of 2008 well. Although growth slowed down significantly in 2009, it remained positive and well above the region's average. A rapid recovery is expected, with growth projected to rise to 5-6 percent in 201011. The banking system showed strong resilience to the crisis and remains on a strong footing, with very low NPLs and high levels of capitalization. Effective supervision and prudent lending behavior were instrumental in limiting exposure to the sectors most affected by the slowdown.

\footnotetext{
${ }^{7}$ The deposit insurance scheme adopted by Hong Kong in the mid-1990s contained similar features.
} 


\section{Box 5. Exchange Rate Assessment}

Panama's real effective exchange rate depreciated in the years leading up to the financial crisis, driven by the weakening of the U.S. dollar. This trend was reverted slightly in 2009, mirroring again movements in the U.S. dollar, which offset the large decline in domestic inflation that took place in Panama.

\section{Model-based estimates suggest that} Panama's real exchange rate was close to its equilibrium level in 2009. Staff used two approaches to assess the level of the real effective exchange rate. The first approach is based on a reduced-form equation of the equilibrium real exchange rate. ${ }^{1}$ This approach shows that the real effective exchange rate was broadly in line with fundamentals (overvaluation of about 1 percent) in 2009. An alternative assessment based on the macroeconomic balance approach estimates the difference between the current account balance projected over the medium term at prevailing exchange rates and an estimated current account balance norm. With a norm of -5 percent of GDP, this approach points to an overvaluation of about 3 percent during 2009.

\footnotetext{
${ }^{1}$ The estimates are based on a vector error correction (VEC) model using annual data for 1980-2009. The fundamentals comprise productivity differentials, terms of trade, trade openness, net foreign liabilities, and the current account balance.
}

27. Fiscal policy helped contain the impact of the adverse external conditions. A relatively strong fiscal position allowed Panama to use fiscal policy to mitigate the effects of lower external demand in 2009. Prudent fiscal management and the economy's momentum, however, did not make it necessary to fully use the scope provided by the modified SFRL to support activity. The strong growth prospects for 2010 make it appropriate to start withdrawing fiscal stimulus.

\section{The fiscal consolidation envisaged in the government's medium-term framework is} appropriately ambitious. The significant decline in the public-debt ratio contemplated in the government's MTFF would create substantial additional space for using fiscal policy to offset the impact of exogenous shocks, which takes on added importance in Panama given its monetary regime. Staff encourages the authorities to adhere to the MTFF targets and use any overperformance to reduce public debt faster.

29. Staff welcomes the sound tax reforms adopted in the last year. The reforms are expected to increase revenues significantly and bolster the credibility of the fiscal framework. By shifting 
taxation from income to consumption and reducing microeconomic distortions, the reforms would also help support long-run economic growth. Staff considers it important to continue moving forward with tax administration reforms, and broaden them to include customs. The Fund stands ready to provide technical assistance to support these efforts.

30. Plans to broaden the financial sector regulation perimeter and introduce risk-

based supervision are welcomed. Nonbank deposit-taking institutions currently not regulated by the SBP should be brought under its umbrella. Staff considers that risk-based supervision would be advantageous for Panama, and help further strengthening bank monitoring. The authorities' preparations to introduce Basel II regulatory requirements and plans to strengthen the regulatory framework for pensions and the insurance sector are also welcomed.

31. There is scope to strengthen the financial safety net. Bank self-insurance against shocks has worked well thus far, but it has risks and costs. Staff is of the view that a formal safety net would lower risks and reduce the need for individual banks to maintain high liquid balances, which are economically costly. The authorities' interest in exploring the possibility of establishing arrangements for emergency liquidity support and a deposit insurance system are welcomed. The Fund stands ready to provide technical assistance in these areas.

32. It is recommended that the next Article IV consultation be held on the 12-month cycle. 
Table 1. Panama: Selected Economic Indicators

I. Social and Demographic Indicators

Population (2008, millions)

Population growth rate (percent a year)

3.4 Percent of population below

Life expectancy at birth (years)

75.4 Adult literacy rate (in percent)

32.4

Under 5 mortality rate (per 1000 live births)

23.1 GDP per capita (USD)

91.9

7,268

II. Economic Indicators, 2006-11

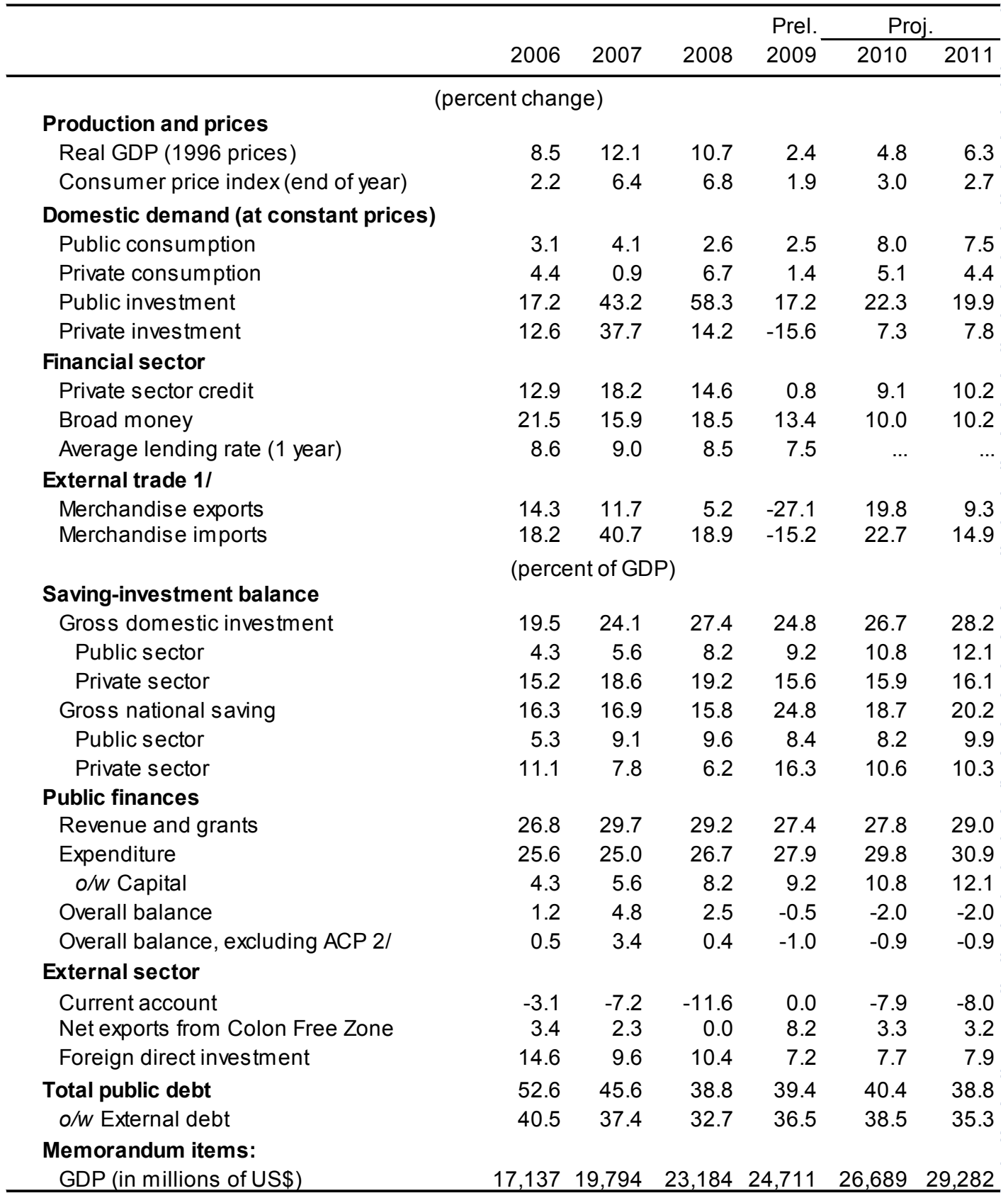

Sources: Comptroller General; World Bank Developments Indicators, and Fund staff estimates.

$1 /$ Excludes the Colon Free Zone.

2/ Panama Canal Authority (ACP). 
Table 2. Panama: Summary Operations of the Nonfinancial Public Sector 1/

(In percent of GDP)

\begin{tabular}{|c|c|c|c|c|c|c|}
\hline & \multirow[b]{2}{*}{2006} & \multirow[b]{2}{*}{2007} & \multirow[b]{2}{*}{2008} & \multirow{2}{*}{$\begin{array}{l}\text { Prel. } \\
2009\end{array}$} & \multicolumn{2}{|c|}{ Proj. } \\
\hline & & & & & 2010 & 2011 \\
\hline Revenues & 24.9 & 27.8 & 25.9 & 24.8 & 25.3 & 26.4 \\
\hline Current revenue & 24.7 & 26.4 & 24.5 & 24.4 & 24.6 & 26.2 \\
\hline Tax revenue & 10.3 & 10.6 & 10.5 & 10.7 & 11.7 & 12.5 \\
\hline \multirow{2}{*}{$\begin{array}{l}\text { Nontax revenue of central government } \\
\text { o/w. Panama Canal fees and dividends }\end{array}$} & 7.7 & 7.9 & 6.7 & 6.3 & 5.8 & 6.3 \\
\hline & 3.5 & 4.3 & 3.0 & 3.2 & 2.8 & 3.4 \\
\hline Social security agency & 5.2 & 5.6 & 5.7 & 5.6 & 5.5 & 5.8 \\
\hline Public enterprise operating balance & 0.7 & 0.8 & 1.2 & 0.9 & 0.9 & 0.9 \\
\hline Other $2 /$ & 0.8 & 1.5 & 0.4 & 1.0 & 0.6 & 0.6 \\
\hline Capital revenue & 0.2 & 1.3 & 1.1 & 0.3 & 0.6 & 0.3 \\
\hline Expenditure & 24.4 & 24.3 & 25.5 & 25.8 & 26.2 & 27.3 \\
\hline Current primary expenditure & 17.0 & 16.0 & 15.4 & 15.8 & 16.1 & 16.2 \\
\hline Central government & 8.8 & 8.2 & 8.2 & 8.3 & 8.3 & 8.4 \\
\hline Rest of the general government & 8.3 & 7.8 & 7.2 & 7.5 & 7.8 & 7.8 \\
\hline Social security agency & 7.3 & 7.0 & 6.5 & 6.8 & 7.1 & 7.1 \\
\hline Decentralized agencies & 0.9 & 0.8 & 0.7 & 0.7 & 0.7 & 0.7 \\
\hline Interest & 4.3 & 3.4 & 3.1 & 2.9 & 2.9 & 2.6 \\
\hline Capital & 3.1 & 4.9 & 7.0 & 7.1 & 7.2 & 8.5 \\
\hline Overall balance, excluding ACP & 0.5 & 3.4 & 0.4 & -1.0 & -0.9 & -0.9 \\
\hline \multicolumn{7}{|l|}{ Panama Canal Authority (ACP) } \\
\hline Revenue & 8.7 & 8.9 & 8.7 & 7.9 & 7.6 & 8.2 \\
\hline Current expenditure & 3.3 & 2.6 & 2.4 & 2.2 & 2.2 & 2.3 \\
\hline Transfers to the government & 3.5 & 4.3 & 3.0 & 3.2 & 2.8 & 3.4 \\
\hline Interest payments & 0.0 & 0.0 & 0.0 & 0.0 & 0.1 & 0.0 \\
\hline Capital expenditure & 1.2 & 0.6 & 1.2 & 2.1 & 3.6 & 3.6 \\
\hline Overall balance & 0.7 & 1.3 & 2.1 & 0.5 & -1.1 & -1.1 \\
\hline Overall balance, including ACP & 1.2 & 4.8 & 2.5 & -0.5 & -2.0 & -2.0 \\
\hline Net financing, excluding ACP & -0.5 & -3.4 & -0.4 & 1.0 & 0.9 & 0.9 \\
\hline External & 0.1 & 2.4 & 0.7 & 6.4 & 0.7 & -0.9 \\
\hline Domestic & -0.5 & -5.9 & -1.1 & -5.3 & 0.2 & 1.8 \\
\hline \multicolumn{7}{|l|}{ Memorandum items: } \\
\hline Savings (including ACP) & 5.3 & 9.1 & 9.6 & 8.4 & 8.2 & 9.9 \\
\hline Primary balance (including ACP) & 5.5 & 8.2 & 5.6 & 2.4 & 1.0 & 0.6 \\
\hline Primary balance (excluding ACP) & 4.8 & 6.9 & 3.5 & 1.8 & 2.0 & 1.7 \\
\hline Public debt & 52.6 & 45.6 & 38.8 & 39.4 & 40.4 & 38.8 \\
\hline GDP (in millions of US\$) & 17,137 & 19,794 & 23,184 & 24,711 & 26,689 & 29,282 \\
\hline
\end{tabular}

Sources: Comptroller General; Ministry of Economy and Finance; and Fund staff estimates and projections.

1/ Official presentation excludes the operations of the ACP which reverted to Panama on December 31, 1999.

$2 /$ Includes the balances of the nonconsolidated public sector and revenue of the decentralized agencies. 
Table 3. Panama: Summary Operations of the Central Government (In percent of GDP)

\begin{tabular}{|c|c|c|c|c|c|c|}
\hline & \multirow[b]{2}{*}{2006} & \multirow[b]{2}{*}{2007} & \multirow[b]{2}{*}{2008} & \multirow{2}{*}{$\begin{array}{l}\text { Prel. } \\
2009\end{array}$} & \multicolumn{2}{|c|}{ Proj. } \\
\hline & & & & & 2010 & 2011 \\
\hline Revenues and grants & 18.6 & 19.2 & 19.7 & 18.0 & 18.9 & 19.7 \\
\hline Current revenue & 18.5 & 18.9 & 18.2 & 17.7 & 18.3 & 19.6 \\
\hline Taxes & 10.3 & 10.6 & 10.5 & 10.7 & 11.7 & 12.5 \\
\hline Direct taxes & 5.7 & 5.5 & 5.4 & 5.7 & 5.5 & 5.4 \\
\hline Income tax & 5.1 & 5.0 & 4.9 & 5.1 & 4.7 & 4.6 \\
\hline Tax on wealth & 0.5 & 0.6 & 0.5 & 0.6 & 0.8 & 0.8 \\
\hline Indirect taxes & 4.6 & 5.0 & 5.1 & 5.0 & 6.2 & 7.0 \\
\hline Import tax & 1.6 & 1.4 & 1.8 & 1.6 & 1.9 & 1.9 \\
\hline ITBMS & 1.9 & 2.6 & 2.3 & 2.3 & 3.0 & 3.6 \\
\hline Petroleum products & 0.5 & 0.5 & 0.4 & 0.5 & 0.5 & 0.5 \\
\hline Other tax on domestic transactions & 0.6 & 0.7 & 0.7 & 0.7 & 0.9 & 1.1 \\
\hline Nontax revenue & 8.2 & 8.4 & 7.7 & 7.0 & 6.6 & 7.1 \\
\hline Dividends & 3.4 & 3.7 & 2.9 & 2.7 & 2.3 & 2.9 \\
\hline Of which: Panama Canal Authority & 2.0 & 2.5 & 1.5 & 1.8 & 1.4 & 2.0 \\
\hline Panama Canal Authority: fees per ton $1 /$ & 1.6 & 1.8 & 1.5 & 1.4 & 1.4 & 1.4 \\
\hline Transfers from decentralized agencies & 1.3 & 1.2 & 1.8 & 1.6 & 1.6 & 1.6 \\
\hline Other & 1.3 & 1.7 & 1.5 & 1.4 & 1.3 & 1.2 \\
\hline Capital revenue & 0.1 & 0.1 & 1.1 & 0.2 & 0.4 & 0.1 \\
\hline Grants & 0.0 & 0.2 & 0.4 & 0.0 & 0.0 & 0.0 \\
\hline Total expenditure & 18.4 & 18.0 & 19.4 & 19.5 & 20.0 & 21.1 \\
\hline Current & 15.9 & 14.0 & 13.8 & 13.3 & 13.7 & 13.4 \\
\hline Wages and salaries & 4.7 & 4.4 & 4.1 & 4.1 & 4.1 & 4.1 \\
\hline Goods and services & 1.8 & 1.5 & 1.8 & 1.7 & 1.7 & 1.8 \\
\hline Pensions & 2.1 & 1.7 & 1.9 & 1.6 & 1.9 & 1.9 \\
\hline Transfers to public and private entities & 3.0 & 3.0 & 2.9 & 3.0 & 3.0 & 3.0 \\
\hline Interest & 4.2 & 3.4 & 3.1 & 2.8 & 2.9 & 2.6 \\
\hline Domestic & 1.0 & 0.4 & 0.4 & 0.3 & 0.2 & 0.1 \\
\hline External & 3.2 & 3.0 & 2.7 & 2.5 & 2.8 & 2.5 \\
\hline Capital & 2.5 & 4.0 & 5.6 & 6.2 & 6.3 & 7.6 \\
\hline Savings $2 /$ & 2.6 & 5.1 & 4.8 & 4.5 & 4.7 & 6.1 \\
\hline Overall balance & 0.2 & 1.2 & 0.3 & -1.4 & -1.1 & -1.4 \\
\hline Financing (net) & -0.2 & -1.2 & -0.3 & 1.4 & 1.2 & 1.4 \\
\hline External & 0.5 & 4.7 & 0.6 & 6.4 & 0.7 & -0.9 \\
\hline Domestic & -0.7 & -5.9 & -0.8 & -4.9 & 0.5 & 2.3 \\
\hline \multicolumn{7}{|l|}{ Memorandum items: } \\
\hline Primary balance & 4.4 & 4.6 & 3.4 & 1.4 & 1.8 & 1.2 \\
\hline GDP (in millions of US\$) & 17,137 & 19,794 & 23,184 & 24,711 & 26,689 & 29,282 \\
\hline
\end{tabular}

Sources: Comptroller General; Ministry of Economy and Finance; and Fund staff estimates and projections.

$1 /$ Includes public service fees.

2/ Revenues and grants less current expenditure. 
Table 4. Panama: Monetary Accounts $1 /$

\begin{tabular}{|c|c|c|c|c|c|c|}
\hline & \multirow[b]{2}{*}{2006} & \multirow[b]{2}{*}{2007} & \multirow[b]{2}{*}{2008} & \multirow{2}{*}{$\begin{array}{l}\text { Prel. } \\
2009\end{array}$} & \multicolumn{2}{|c|}{ Proj. } \\
\hline & & & & & 2010 & 2011 \\
\hline & \multicolumn{6}{|c|}{ (In millions of U.S. dollars at end-period) } \\
\hline Net foreign assets & 4,113 & 5,257 & 6,042 & 8,614 & 8,566 & 8,364 \\
\hline Short-term foreign assets, net & 4,131 & 5,272 & 6,050 & 8,619 & 8,571 & 8,369 \\
\hline National Bank of Panama & 1,421 & 2,028 & 2,695 & 3,388 & 3,488 & 3,788 \\
\hline Rest of banking system & 2,710 & 3,244 & 3,355 & 5,231 & 5,083 & 4,581 \\
\hline Long-term foreign liabilities & 18 & 14 & 8 & 5 & 5 & 5 \\
\hline National Bank of Panama & 18 & 14 & 8 & 5 & 5 & 5 \\
\hline Net domestic assets & 10,694 & 11,911 & 15,061 & 14,732 & 16,798 & 19,587 \\
\hline Public sector (net credit) & $-1,442$ & $-2,435$ & $-2,465$ & $-2,860$ & $-1,322$ & -340 \\
\hline Central government (net credit) & 134 & -314 & -456 & -176 & -127 & -59 \\
\hline Rest of the public sector (net credit) & $-1,577$ & $-2,121$ & $-2,009$ & $-2,684$ & $-1,195$ & -281 \\
\hline Private sector credit & 15,681 & 18,540 & 21,245 & 21,407 & 23,362 & 25,726 \\
\hline Private capital and surplus & $-3,917$ & $-5,578$ & $-6,419$ & $-5,573$ & $-6,103$ & $-6,726$ \\
\hline Other assets (net) & 372 & 1,383 & 2,700 & 1,758 & 861 & 927 \\
\hline Liabilities to private sector & 14,807 & 17,167 & 20,335 & 23,063 & 25,364 & 27,951 \\
\hline Total deposits & 14,739 & 17,100 & 20,274 & 22,968 & 25,259 & 27,836 \\
\hline Demand deposits & 2,615 & 3,042 & 3,762 & 5,175 & 5,589 & 6,132 \\
\hline Time deposits & 9,283 & 10,536 & 12,165 & 12,940 & 13,976 & 15,334 \\
\hline Savings deposits & 2,840 & 3,522 & 4,347 & 4,853 & 5,695 & 6,371 \\
\hline \multirow[t]{2}{*}{ Bonds } & 68 & 67 & 61 & 95 & 104 & 115 \\
\hline & \multicolumn{6}{|c|}{$\begin{array}{l}\text { (12-month change in relation to liabilities to the private } \\
\text { sector at the beginning of the period) }\end{array}$} \\
\hline Net foreign assets & 9.8 & 7.7 & 4.6 & 12.6 & -0.2 & -0.8 \\
\hline Net domestic assets & 11.7 & 8.2 & 18.4 & -1.6 & 9.0 & 11.0 \\
\hline Public sector credit (net) & -1.6 & -6.7 & -0.2 & -1.9 & 6.7 & 3.9 \\
\hline Private sector credit & 14.7 & 19.3 & 15.8 & 0.8 & 8.5 & 9.3 \\
\hline Private capital and surplus & 3.1 & 11.2 & 4.9 & -4.2 & 2.3 & 2.5 \\
\hline Other assets (net) & 1.7 & 6.8 & 7.7 & -4.6 & -3.9 & 0.3 \\
\hline Liabilities to the private sector & 21.5 & 15.9 & 18.5 & 13.4 & 10.0 & 10.2 \\
\hline & \multicolumn{6}{|c|}{ (12-month percent change) } \\
\hline \multicolumn{7}{|l|}{ Memorandum items: } \\
\hline M2 2/ & 21.5 & 15.9 & 18.5 & 13.4 & 10.0 & 10.2 \\
\hline \multirow[t]{2}{*}{ Private sector credit } & 12.9 & 18.2 & 14.6 & 0.8 & 9.1 & 10.1 \\
\hline & \multicolumn{6}{|c|}{ (In percent of GDP) } \\
\hline Total deposits & 86.0 & 86.4 & 87.4 & 92.9 & 94.6 & 95.1 \\
\hline Private sector credit & 91.5 & 93.7 & 91.6 & 86.6 & 87.5 & 87.9 \\
\hline
\end{tabular}

Sources: Superintendency of Banks; National Bank of Panama; Savings Bank; and Fund staff estimates and projections.

1/ Domestic banking system only; comprises general license banks; does not include offshore banks; deposits from and credit to nonresidents reported in the net foreign assets.

2/ M2 consists of bank deposits only; estimates of U.S. currency in circulation are not available. 
Table 5. Panama: Commercial Bank Performance Indicators 1/

(In percent; end-of-period)

\begin{tabular}{|c|c|c|c|c|c|}
\hline & \multirow[b]{2}{*}{2007} & \multirow[b]{2}{*}{2008} & \multicolumn{2}{|c|}{2009} & \multirow{2}{*}{$\frac{2010}{\text { Mar. }}$} \\
\hline & & & Jun. & Dec. & \\
\hline \multicolumn{6}{|l|}{ Asset quality } \\
\hline \multicolumn{6}{|c|}{ Nonperforming loans as percent of total loans } \\
\hline Banking system & 1.3 & 1.6 & 1.4 & 1.4 & 1.4 \\
\hline Domestic banks & 1.5 & 1.7 & 1.5 & 1.3 & 1.3 \\
\hline Foreign banks & 1.2 & 1.7 & 1.3 & 1.5 & 1.5 \\
\hline \multicolumn{6}{|c|}{ Ratio of provisions to nonperforming loans } \\
\hline Banking system & 141.7 & 104.8 & 116.3 & 120.0 & 122.4 \\
\hline Domestic banks & 147.8 & 120.2 & 125.2 & 150.3 & 153.2 \\
\hline Foreign banks & 136.0 & 93.5 & 109.0 & 99.6 & 100.5 \\
\hline \multicolumn{6}{|c|}{ Profitability } \\
\hline \multicolumn{6}{|c|}{ Pretax return on average assets } \\
\hline Banking system & 2.0 & 2.2 & 1.7 & 1.4 & 1.5 \\
\hline Domestic banks & 1.9 & 2.9 & 1.4 & 1.4 & 1.5 \\
\hline Foreign banks & 2.0 & 2.7 & 2.0 & 1.4 & 1.6 \\
\hline \multicolumn{6}{|l|}{ Liquidity } \\
\hline \multicolumn{6}{|c|}{ Ratio of liquid assets to total deposits } \\
\hline Banking system & 23.4 & 28.4 & 25.9 & 28.4 & 26.4 \\
\hline Domestic banks & 26.1 & 25.9 & 25.8 & 27.6 & 25.9 \\
\hline Foreign banks & 27.3 & 30.6 & 26.0 & 29.3 & 26.8 \\
\hline \multicolumn{6}{|c|}{$\begin{array}{l}\text { Ratio of liquid assets plus marketable } \\
\text { securities to total deposits } 2 /\end{array}$} \\
\hline Banking system & 40.9 & 43.0 & 41.1 & 42.9 & 42.1 \\
\hline Domestic banks & 39.5 & 39.0 & 39.4 & 39.9 & 39.3 \\
\hline Foreign banks & 41.9 & 46.2 & 42.4 & 45.7 & 44.6 \\
\hline \multicolumn{6}{|c|}{ Capital adequacy ratios } \\
\hline \multicolumn{6}{|c|}{ Ratio of capital to risk-weighted assets } \\
\hline Banking system & 14.5 & 14.8 & 15.6 & 16.4 & 16.6 \\
\hline Domestic banks & 18.8 & 17.8 & 18.4 & 18.8 & 19.6 \\
\hline Foreign banks & 12.0 & 13.0 & 14.0 & 15.3 & 15.3 \\
\hline \multicolumn{6}{|c|}{ Ownership } \\
\hline \multicolumn{6}{|c|}{ Foreign banks' share of domestic banking } \\
\hline system assets & 60.9 & 58.3 & 55.4 & 54.7 & 53.6 \\
\hline
\end{tabular}

Sources: Superintendency of Banks; and Fund staff estimates.

$1 /$ Domestic banking system only, comprises general license banks; does not include offshore banks.

2/ Liquid assets, as defined in Article 48 of the Banking Law, also include marketable short-term securities. 
Table 6. Panama: Medium-Term Macroeconomic Framework

\begin{tabular}{|c|c|c|c|c|c|c|c|c|c|}
\hline & \multirow[b]{2}{*}{2007} & \multirow[b]{2}{*}{2008} & \multirow{2}{*}{$\begin{array}{l}\text { Prel. } \\
2009\end{array}$} & \multicolumn{6}{|c|}{ Proj. } \\
\hline & & & & 2010 & 2011 & 2012 & 2013 & 2014 & 2015 \\
\hline & \multicolumn{9}{|c|}{ (Percent change) } \\
\hline \multicolumn{10}{|l|}{ Economic growth and prices } \\
\hline Real GDP at market prices & 12.1 & 10.7 & 2.4 & 4.8 & 6.3 & 6.5 & 6.2 & 6.2 & 6.5 \\
\hline GDP deflator & 3.0 & 5.8 & 4.1 & 3.0 & 3.2 & 3.2 & 3.2 & 3.2 & 3.2 \\
\hline $\mathrm{CPI}$ (period average) & 4.2 & 8.8 & 2.4 & 3.3 & 2.8 & 2.6 & 2.5 & 2.5 & 2.5 \\
\hline \multirow[t]{2}{*}{$\mathrm{CPI}$ (end of period) } & 6.4 & 6.8 & 1.9 & 3.0 & 2.7 & 2.5 & 2.5 & 2.5 & 2.5 \\
\hline & \multicolumn{9}{|c|}{ (Percent of GDP) } \\
\hline \multicolumn{10}{|l|}{ Savings and investment } \\
\hline National savings & 16.9 & 15.8 & 24.8 & 18.7 & 20.2 & 19.8 & 20.0 & 21.1 & 22.1 \\
\hline Public sector & 9.1 & 9.6 & 8.4 & 8.2 & 9.9 & 9.5 & 9.6 & 9.7 & 10.1 \\
\hline Private sector & 7.8 & 6.2 & 16.3 & 10.6 & 10.3 & 10.3 & 10.5 & 11.3 & 12.0 \\
\hline Gross domestic investment & 24.1 & 27.4 & 24.8 & 26.7 & 28.2 & 28.3 & 27.8 & 26.9 & 26.6 \\
\hline Public sector & 5.6 & 8.2 & 9.2 & 10.8 & 12.1 & 11.8 & 11.0 & 9.8 & 9.3 \\
\hline Of which: Canal Expansion & & 0.7 & 0.6 & 3.0 & 3.0 & 3.1 & 2.4 & 1.3 & 0.8 \\
\hline Private sector & 18.6 & 19.2 & 15.6 & 15.9 & 16.1 & 16.5 & 16.8 & 17.1 & 17.3 \\
\hline External savings & -7.2 & -11.6 & 0.0 & -7.9 & -8.0 & -8.5 & -7.7 & -5.9 & -4.5 \\
\hline \multicolumn{10}{|l|}{ Nonfinancial public sector, excluding ACP } \\
\hline Revenue & 27.8 & 25.9 & 24.8 & 25.3 & 26.4 & 26.4 & 26.7 & 26.6 & 26.8 \\
\hline Revenue, excluding ACP transfers & 23.5 & 22.9 & 21.6 & 22.4 & 23.0 & 23.0 & 23.2 & 23.2 & 23.2 \\
\hline Expenditure & 24.3 & 25.5 & 25.8 & 26.2 & 27.3 & 27.0 & 26.7 & 26.4 & 26.3 \\
\hline Primary balance & 6.9 & 3.5 & 1.8 & 2.0 & 1.7 & 2.0 & 2.3 & 2.3 & 2.5 \\
\hline Overall balance & 3.4 & 0.4 & -1.0 & -0.9 & -0.9 & -0.5 & -0.1 & 0.3 & 0.5 \\
\hline Net external financing & 2.4 & 0.7 & 6.4 & 0.7 & -0.9 & 0.8 & 0.5 & 0.8 & -0.6 \\
\hline Net domestic financing & -5.9 & -1.1 & -5.3 & 0.2 & 1.8 & -0.2 & -0.4 & -1.0 & 0.2 \\
\hline \multicolumn{10}{|l|}{ Panama Canal Authority (ACP) } \\
\hline Revenue & 8.9 & 8.7 & 7.9 & 7.6 & 8.2 & 8.0 & 7.9 & 7.9 & 8.3 \\
\hline Current expenditure & 2.6 & 2.4 & 2.2 & 2.2 & 2.3 & 2.4 & 2.5 & 2.6 & 2.7 \\
\hline Transfers to the government & 4.3 & 3.0 & 3.2 & 2.8 & 3.4 & 3.4 & 3.4 & 3.4 & 3.6 \\
\hline Interest payments & 0.0 & 0.0 & 0.0 & 0.1 & 0.0 & 0.1 & 0.2 & 0.2 & 0.2 \\
\hline Capital expenditure & 0.6 & 1.2 & 2.1 & 3.6 & 3.6 & 3.6 & 2.9 & 1.8 & 1.2 \\
\hline Overall balance & 1.3 & 2.1 & 0.5 & -1.1 & -1.1 & -1.6 & -1.0 & 0.0 & 0.6 \\
\hline \multicolumn{10}{|l|}{ Nonfinancial public sector, including ACP } \\
\hline Overall balance & 4.8 & 2.5 & -0.5 & -2.0 & -2.0 & -2.1 & -1.1 & 0.2 & 1.1 \\
\hline Total public debt & 45.6 & 38.8 & 39.4 & 40.4 & 38.8 & 37.4 & 35.2 & 31.9 & 28.5 \\
\hline$o / w: A C P$ & 0.0 & 0.0 & 0.0 & 1.1 & 2.1 & 3.5 & 4.2 & 3.9 & 3.5 \\
\hline \multicolumn{10}{|l|}{ External } \\
\hline Exports, f.o.b., excluding Colón Free Zone & 8.3 & 7.4 & 5.1 & 5.6 & 5.6 & 5.7 & 5.8 & 6.0 & 6.1 \\
\hline Imports, f.o.b., excluding Colón Free Zone & -26.7 & -27.1 & -21.5 & -24.5 & -25.6 & -26.5 & -26.3 & -24.7 & -23.9 \\
\hline Net exports of Colón Free Zone & 2.3 & 0.0 & 8.2 & 3.3 & 3.2 & 3.3 & 3.4 & 3.4 & 3.4 \\
\hline Current account balance & -7.2 & -11.6 & 0.0 & -7.9 & -8.0 & -8.5 & -7.7 & -5.9 & -4.5 \\
\hline \multirow[t]{2}{*}{ Foreign Direct Investment } & 9.6 & 10.4 & 7.2 & 7.7 & 7.9 & 8.0 & 8.0 & 8.1 & 8.1 \\
\hline & \multicolumn{9}{|c|}{ (In millions of U.S. dollars) } \\
\hline \multicolumn{10}{|l|}{ Memorandum items: } \\
\hline Nominal GDP & 19,794 & 23,184 & 24,711 & 26,689 & 29,282 & 32,164 & 35,266 & 38,676 & 42,537 \\
\hline External Debt (excluding banks, percent of GDP) & 52.6 & 46.7 & 52.5 & 53.8 & 50.5 & 49.6 & 48.2 & 46.0 & 42.5 \\
\hline External Debt (including banks, percent of GDP) 1/ & 176.6 & 167.9 & 163.3 & 164.6 & 161.3 & 160.6 & 159.4 & 157.4 & 154.2 \\
\hline Structural primary balance, excluding ACP & 6.7 & 2.8 & 2.1 & 2.4 & 2.0 & 2.3 & 2.6 & 2.5 & 2.5 \\
\hline
\end{tabular}

Sources: Office of the Comptroller General; Ministry of Economy and Finance; and Fund staff estimates and projections.

$1 /$ Includes offshore banks. 
Table 7. Panama: Medium-Term Balance of Payments

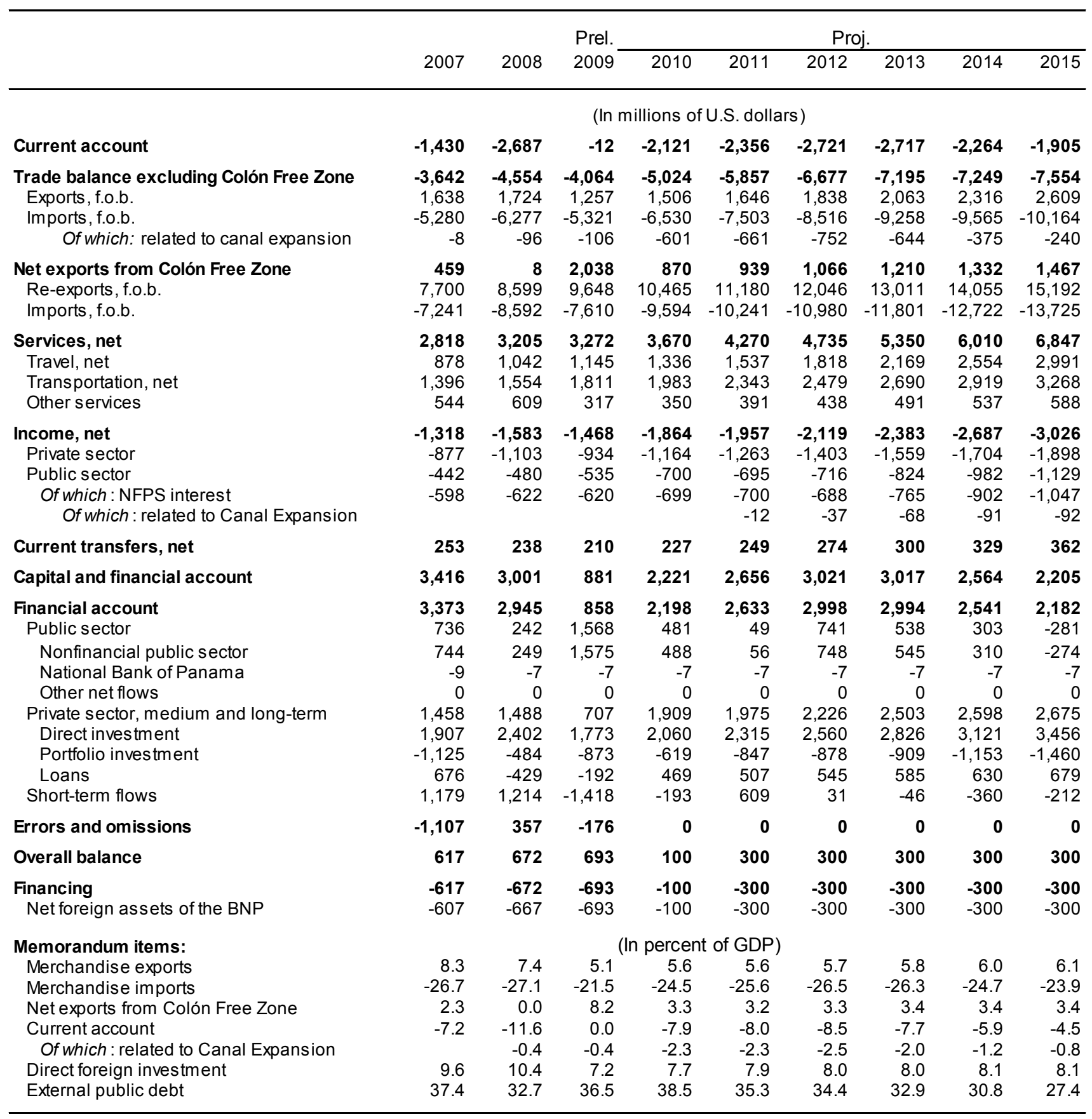

Sources: Office of the Comptroller General; and Fund staff estimates and projections. 
Table 8. Panama: Debt of the Nonfinancial Public Sector

\begin{tabular}{|c|c|c|c|c|c|}
\hline & 2006 & 2007 & 2008 & $\begin{array}{l}\text { Prel. } \\
2009\end{array}$ & $\begin{array}{l}\text { Proj. } \\
2010\end{array}$ \\
\hline \multicolumn{6}{|c|}{ (In millions of U.S. dollars) } \\
\hline External debt $1 /$ & 6,933 & 7,404 & 7,586 & 9,018 & 10,266 \\
\hline Multilaterals & 1,183 & 1,235 & 1,350 & 1,594 & 1,783 \\
\hline IBRD & 188 & 217 & 271 & 435 & 450 \\
\hline IDB & 883 & 891 & 948 & 1,028 & 1,095 \\
\hline Others & 111 & 127 & 130 & 130 & 237 \\
\hline Bilateral and guaranteed suppliers & 237 & 224 & 210 & 219 & 227 \\
\hline Commercial banks & 8 & 6 & 170 & 219 & 217 \\
\hline $\begin{array}{l}\text { Global bonds } \\
\text { ACP 2/ }\end{array}$ & $\begin{array}{r}5,505 \\
0\end{array}$ & $\begin{array}{r}5,938 \\
0\end{array}$ & $\begin{array}{r}5,856 \\
0\end{array}$ & $\begin{array}{r}6,986 \\
0\end{array}$ & $\begin{array}{r}7,746 \\
293\end{array}$ \\
\hline Domestic debt $3 /$ & 2,081 & 1,631 & 1,419 & 708 & 508 \\
\hline Private creditors & 1,313 & 994 & 828 & 518 & 318 \\
\hline Public financial institutions & 768 & 636 & 591 & 190 & 190 \\
\hline Total Public Debt & 9,014 & 9,034 & 9,005 & 9,726 & 10,774 \\
\hline \multicolumn{6}{|c|}{ (In percent of GDP) } \\
\hline Total & 52.6 & 45.6 & 38.8 & 39.4 & 40.4 \\
\hline External & 40.5 & 37.4 & 32.7 & 36.5 & 38.5 \\
\hline Domestic & 12.1 & 8.2 & 6.1 & 2.9 & 1.9 \\
\hline \multicolumn{6}{|l|}{ Memorandum items: } \\
\hline Held by Fiduciary Fund ( In percent of GDP ) & 5.0 & 4.4 & 3.8 & 4.4 & 1.2 \\
\hline Held by Social Security Agency (In percent of GDP) & 3.4 & 2.8 & 2.3 & 0.0 & 1.0 \\
\hline GDP (in millions of U.S. dollars) & 17,137 & 19,794 & 23,184 & 24,711 & 26,689 \\
\hline
\end{tabular}

Sources: Comptroller General; Ministry of Economy and Finance; and Fund staff estimates and projections.

1/ Excludes assets held by the Fiduciary Fund.

2/ Reflects disbursements from multilateral development banks and JBIC for the Panama Canal expansion.

3/ Excludes government debt held by the Social Security Agency. 
Table 9. Panama: Vulnerability Indicators

\begin{tabular}{|c|c|c|c|c|c|}
\hline & 2005 & 2006 & 2007 & 2008 & $\begin{array}{l}\text { Prel. } \\
2009\end{array}$ \\
\hline \multicolumn{6}{|l|}{ Financial indicators } \\
\hline Broad money (12-month percent change) & 8.5 & 21.5 & 15.9 & 18.5 & 13.4 \\
\hline Private sector credit (12-month percent change) & 13.3 & 12.9 & 18.2 & 14.6 & 0.8 \\
\hline Deposit rate (6-month; in percent) $1 /$ & 3.2 & 5.1 & 4.6 & 3.5 & 3.6 \\
\hline \multicolumn{6}{|l|}{ External indicators } \\
\hline Merchandise exports (12-month percent change) & 11.9 & 14.3 & 11.7 & 5.2 & -27.1 \\
\hline Merchandise imports (12-month percent change) & 14.3 & 18.2 & 40.7 & 18.9 & -15.2 \\
\hline Current account balance (in percent of GDP) & -4.9 & -3.1 & -7.2 & -11.6 & 0.0 \\
\hline Capital and financial account balance & 15.0 & 0.9 & 15.9 & 12.9 & 3.6 \\
\hline Of which: direct investment & 6.2 & 14.6 & 9.6 & 10.4 & 7.2 \\
\hline Public sector external debt & 45.5 & 40.5 & 37.4 & 32.7 & 36.5 \\
\hline In percent of exports of goods and services 2/ & 138.5 & 115.9 & 105.4 & 100.4 & 103.3 \\
\hline $\begin{array}{l}\text { External interest payments (in percent of } \\
\text { Exports of goods and services) } 2 /\end{array}$ & 10.3 & 8.2 & 7.5 & 7.4 & 6.4 \\
\hline \multicolumn{6}{|l|}{ External amortization payments (in percent of } \\
\hline Exports of goods and services) $2 /$ & 19.7 & 35.1 & 2.5 & 12.3 & 2.4 \\
\hline REER, percent change (depreciation -) 3/ & 6.6 & -4.6 & -2.0 & 3.2 & -5.0 \\
\hline \multicolumn{6}{|l|}{ Gross international reserves at end of period } \\
\hline In millions of U.S. dollars $4 /$ & 1,236 & 1,440 & 2,044 & 2,710 & 3,406 \\
\hline In months of imports of goods and services & 3.0 & 3.2 & 3.3 & 3.6 & 5.4 \\
\hline In percent of broad money & 10.1 & 9.7 & 11.9 & 13.3 & 14.8 \\
\hline \multirow[t]{2}{*}{ In percent of short-term external debt $5 /$} & 119.1 & 817.8 & 539.9 & 1285.4 & 2694.2 \\
\hline & \multicolumn{5}{|c|}{ (In millions of U.S. dollars) } \\
\hline \multicolumn{6}{|l|}{ Memorandum items: } \\
\hline Nominal GDP & 15,465 & 17,137 & 19,794 & 23,184 & 24,711 \\
\hline Exports of goods and services $2 /$ & 5,076 & 5,979 & 7,022 & 7,557 & 8,732 \\
\hline
\end{tabular}

Sources: Ministry of Economy and Finance; and Fund staff estimates and projections.

1/ One-year average for the banking system, comprising of general license banks, excluding offshore banks.

2/ Includes net exports of the Colón Free Zone.

3/ Data for end of period.

4/ Corresponds to gross foreign assets of the National Bank of Panama (a publicly-owned commercial bank).

5/ Short-term public external debt includes amortization in the following year.

Excludes global bonds debt exchange operations. 
Table 10. Panama: Public Sector Debt Sustainability Framework, $\underline{2006-2015}$

(In percent of GDP, unless otherwise indicated)

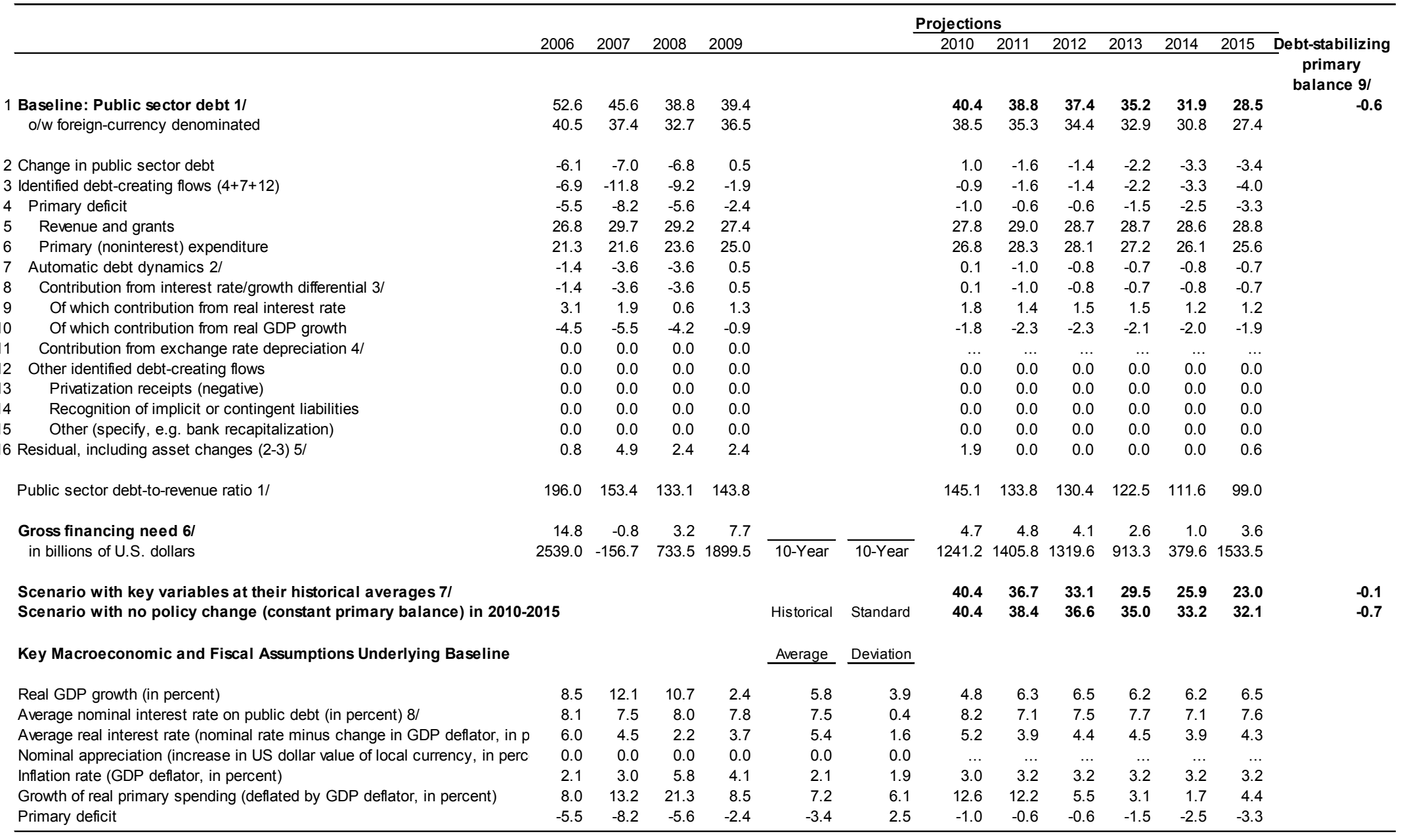

1/Nonfinancial public sector, includes ACP.

2/ Derived as $[(r-\pi(1+g)-g+\alpha \cdot(1+r)](1+g+\pi+g \pi))$ times previous period debt ratio, with $r=$ interest rate; $\pi=$ growth rate of GDP deflator; $g=$ real GDP growth rate; $\alpha=$ share of foreign-currency denominated debt; and $\varepsilon=$ nominal exchange rate depreciation (measured by increase in local currency value of U.S. dollar).

$3 /$ The real interest rate contribution is derived from the denominator in footnote $2 /$ as $r-\pi(1+g)$ and the real growth contribution as $-\mathrm{g}$.

$4 /$ The exchange rate contribution is derived from the numerator in footnote $2 /$ as $\alpha \varepsilon(1+r)$.

$5 /$ For projections, this line includes exchange rate changes.

7/Defined as public sector defict, plus amortzation of medium and long-term public sector debt, plus short-term debt at end of previous period.

7T The key variables include real GDP growth; real interest rate; and primary balance in percent of GDP.

$9 /$ Assumes that key variables (real GDP growth, real interest rate, and other identified debt-creating flows) remain at the level of the last projection year. 
Figure 5. Panama: Public Debt Sustainability: Bound Tests 1/ (Public debt in percent of GDP)

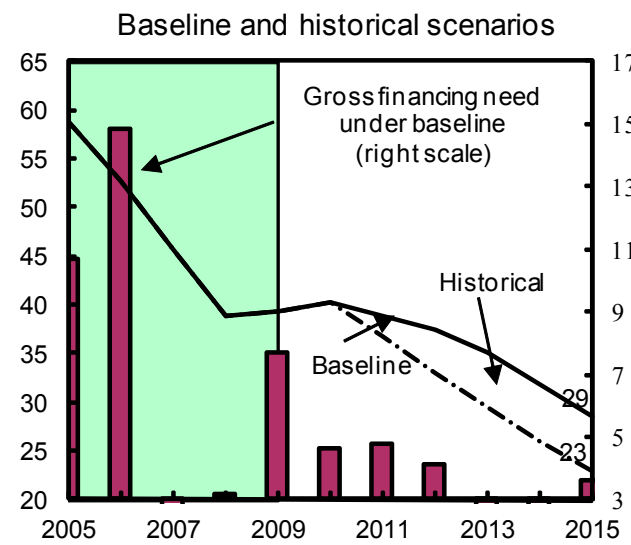

Growth shock (in percent per year)

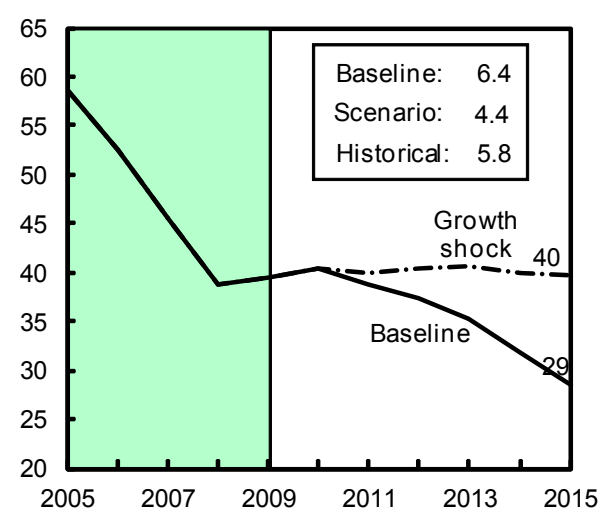

Combined shock 2/

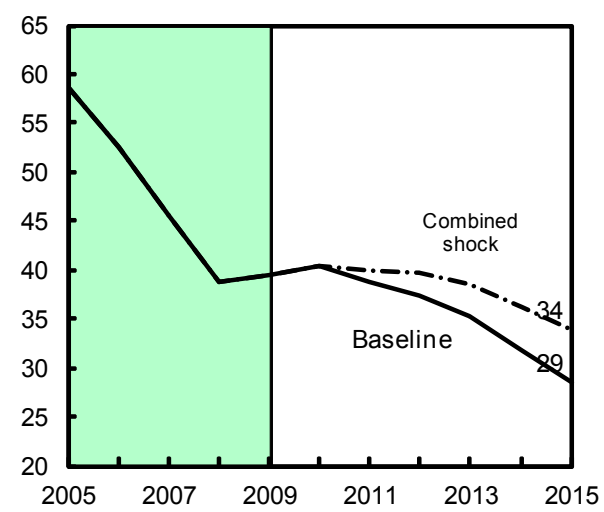

Interest rate shock (in percent)
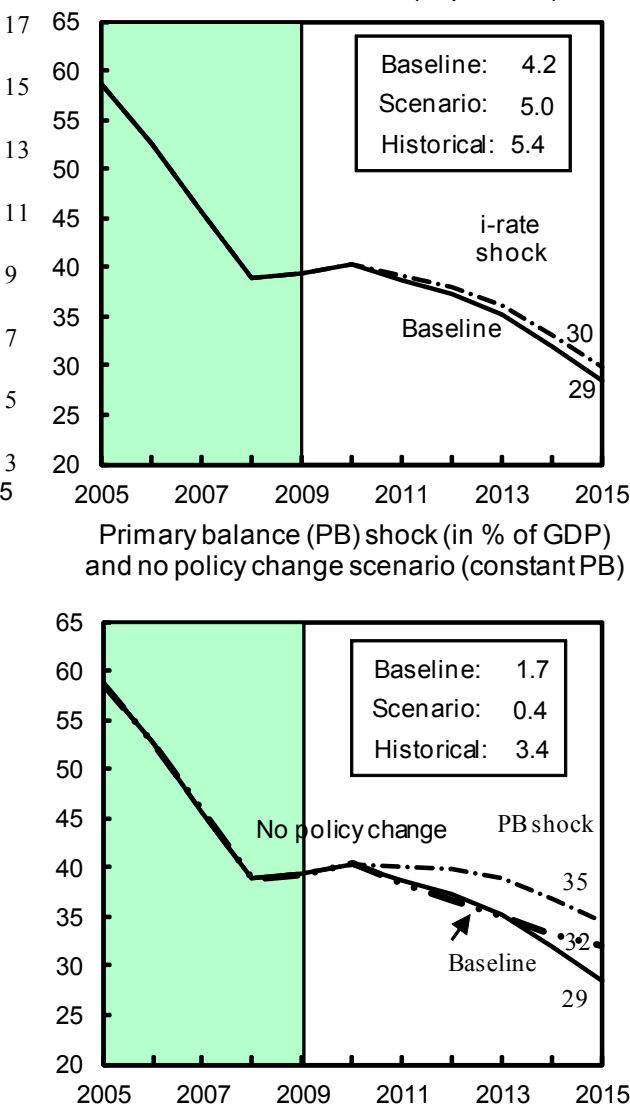

Contingent liabilities shock $3 /$

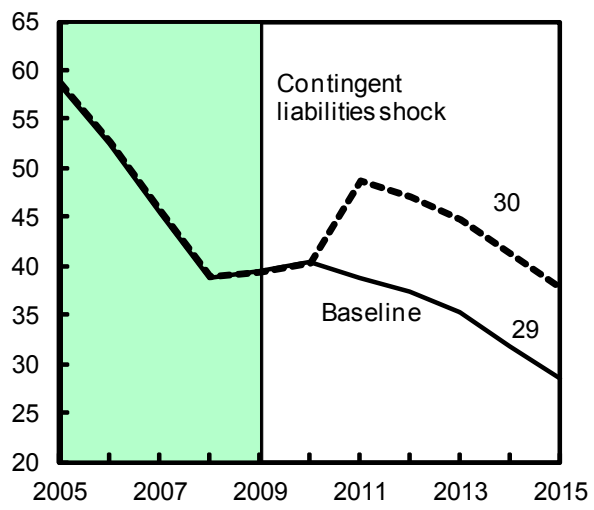

Sources: In temational Monetary Fund, country desk data, and staff estimates. 1/Shaded areas represent actual data. In dividual shocks are permanent one-half standard deviation shocks. Figures in the boxes represent average projections for the respective variables in the baseline and scenario being presented. Ten-yearh istorical average for the variable is also shown.

2/ Permanent $1 / 4$ standard deviation shocks ap plied to real interest rate, growth rate, and primary balance. 3/ A 10 percent of GDP shock to contingent liabilities occurs in 2010. 


\section{ANNEX I. SUMmARY OF ANNEXES}

The full annexes of this report may be viewed on the Fund's intranet and on the secure extranet for Executive Directors and member-country officials.

\section{Fund relations}

As of April 30, 2010, Panama did not have any outstanding purchases or loans. The latest precautionary SBA expired on March 29, 2002. The last Article IV consultation was completed by the Executive Board on June 1, 2009. Panama has received TA from the Fund in recent years, including on national accounts statistics in March 2009. The last safeguards assessment was completed on July 12, 2001, and concluded that the National Bank of Panama's external-audit mechanism was adequate at the time. There is no resident representative.

\section{Relations with the World Bank}

The Country Partnership Strategy (CPS) for Fiscal Year (FY) 2008-10 was approved in October 2007 and consists of a mix of analytical and advisory assistance, development policy loans, and investment operations. A new CPS for FY 2011-14 is being prepared and is expected to be discussed by the Board later this year.

\section{Relations with the Inter-American Development Bank}

For 2010, the Bank is working on four loans in the areas of urban transportation (US\$600 million), road infrastructure (US\$70 million), water and sanitation (US\$40 million), and education (US\$30 million). The IDB is expected to finish the country strategy for the 2010-14 period later this year.

\section{Statistical Issues}

Panama's economic statistics and data provisions have some shortcomings, but are broadly adequate for surveillance. 


\title{
INTERNATIONAL MONETARY FUND
}

PANAMA

\section{Staff Report for the 2010 Article IV Consultation \\ Informational Annex}

\author{
Prepared by Western Hemisphere Department
}

(In collaboration with other departments)

June 25,2010

Contents

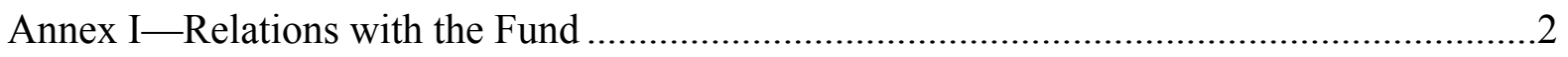

Annex II—Relations with the World Bank …………........................................................

Annex III—Relations with the Inter-American Development Bank .......................................6

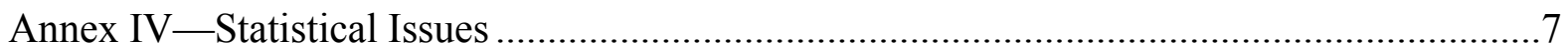




\section{ANNEX I-RELATIONS WITH THE FUND}

(As of May 31, 2010)

I. Membership Status: Joined March 14, 1946; Article VIII.

\section{A. Financial Relations}

II. General Resources Account:

SDR Million

206.60

194.75

11.86

Fund holdings of currency
Reserve position in the Fund

III. SDR Department:

Net cumulative allocation

Holdings

IV. Outstanding Purchases and Loans:

None

V. Financial Arrangements:

Type

Approval

Date

Stand-By

EFF

Stand-By
SDR Million

197.01

171.05

SDR Million
Percent

of Quota

100.00

94.27

5.74

Percent

Allocation

100.0

86.82

Percent

of Quota

VI. Projected Obligations to the Fund: (SDR Million; based on existing use of resources and present holdings of SDRs):

\section{Forthcoming}

\begin{tabular}{lllll}
\hline$\underline{2010}$ & $\underline{2011}$ & $\underline{2012}$ & $\underline{2013}$ & $\underline{2014}$
\end{tabular}

Principal

Charges/interest

0.05

0.07

0.07

0.07

0.07

Total

0.05

0.07

0.07

0.07

0.07

Amount Drawn (SDR million)

64.00

0.00

40.00

84.30

20.00




\section{Safeguards Assessment}

Under the Fund's safeguards assessment policy, the National Bank of Panama (NBP) was subject to the transitional procedures with respect to the Stand-By Arrangement, which was approved on June 30, 2000, and expired on March 29, 2002. The transitional procedures required a review of the NBP's external audit mechanism only. The assessment was completed on July 12, 2001 and concluded that NBP's external audit mechanism was at the time adequate, as reported in SM/02/160, May 22, 2002.

\section{B. Nonfinancial Relations}

\section{Exchange Rate Arrangement:}

Panama uses the U.S. dollar as the primary means of payment in the local economy. Its national currency (balboa) is issued in the form of coins only and serves as a unit of account. The exchange rate of the balboa is fixed at B 1 per U.S. dollar. Panama has accepted the obligations of Article VIII, Sections 2(a), 3, and 4, and maintains an exchange system that is free of restrictions on the making of payments and transfers for current international transactions.

\section{Last Article IV Consultation:}

The 2008 Article IV consultation was concluded on June 1, 2009. Panama is on the standard 12-month consultation cycle.

\section{Technical Assistance:}

STA: March 2009, National Accounts statistics mission to evaluate the compilation of output and value added of financial services.

March 2007, assistance to improve and regionally harmonize monetary and financial statistics reporting.

December 2006, assistance to improve fiscal data quality.

FAD: October 2005, fiscal ROSC assessment mission.

MCM: February 2008, in conjunction with WHD, a mission to assess the implications of the increased presence of foreign banks in Central America for bank supervision.

October/November 2007, assistance with drafting a revised Bank Law;

May/June 2005 and November 2005, an assessment of financial sector supervision and regulation.

May/June 2005, Offshore Financial Sector Initiative mission to follow-up on the evaluation of the 2001 Module 2 assessment.

\section{Resident Representative: :}

None 


\section{ANNEX II-RELATIONS WITH THE WORLD BANK}

1. The Country Partnership Strategy (CPS) for Fiscal Year (FY) 2008-10 was approved in October 2007 and consists of a mix of analytical and advisory assistance, development policy loans, and investment operations. The CPS has aimed to provide selective, demand-driven assistance to help Panama achieve its growth and poverty and inequality reduction goals. A new CPS for FY 2011-14 is being prepared for the fall of 2010.

2. Since the CPS became effective, about US\$332.3 million has been disbursed, divided into three Development Policy Loans (DPLs), seven new poverty-focused investment projects, and one Technical Assistance (TA) loan. The current portfolio consists of five IBRD projects and a GEF donation under implementation, totaling US\$204.5 million, of which US\$116.4 million is undisbursed. The Protecting the Poor under Global Uncertainty DPL (US\$80 million) was approved in the spring of 2009 to support country efforts to mitigate the impact of economic shocks on the poor through improved targeting and coverage of social sector programs. The existing project portfolio consists of the Social Protection Project, the Health Equity and Performance Improvement Project, the Water and Sanitation Project, the Land Administration Project, the Rural Productivity Project, and the Global Environment Facility Rural Productivity Project.

3. The Bank is also providing analytical and technical assistance to Panama. A set of Policy Notes was prepared to support the government transition with information on key development challenges as well as policies and programs to confront them. Analytical assistance was also provided on poverty measurement and enhancing government procurement and financial management systems.

4. The staffs of the World Bank and the IMF are working in close collaboration, including frequent exchange of data and information and coordination of policy advice. 
Panama: Financial Relations with the World Bank Group

(In Millions of U.S. dollars)

\section{A. Active IBRD Operations}

(As of June 2, 2010)

IBRD projects

1 Social Protection

2 Land Administration

3 Rural Productivity

4 GEF Rural Productivity

5 Water and Sanitation

6 Health Equity and Performance Improvement Total
Commitment

24.0

47.9

39.4

6.0

32.0

40.0

189.3
Undisbursed

16.6

3.0

32.0

4.5

27.2

33.1

116.4

\section{B. IBRD Loan Disbursements}

(Fiscal Year)

Number of projects

Commitment amount

Total of undisbursed balance

$\begin{array}{rrrrrrrr}\mathbf{2 0 0 3} & \mathbf{2 0 0 4} & \mathbf{2 0 0 5} & \mathbf{2 0 0 6} & \mathbf{2 0 0 7} & \mathbf{2 0 0 8} & \mathbf{2 0 0 9} & \mathbf{2 0 1 0} \\ 8 & 4 & 3 & 3 & 4 & 7 & 9 & 6 \\ 220.9 & 97.7 & 93.4 & 93.4 & 138.8 & 274.8 & 414.8 & 198.5 \\ 97.2 & 68.1 & 60.3 & 51.4 & 78.9 & 118.7 & 170.9 & 118.6\end{array}$




\section{ANNEX III-RELATIONS WITH THE INTER-AMERICAN DEVELOPMENT BANK}

1. During the second half of 2010 the IDB is expected to finish the country strategy for the 2010-14 period.

As of June 2010, the IDB has pending disbursements for US\$422.5 millions, this amount corresponds to public sector guaranteed loans and are mostly concentrated on the disaster prevention, state modernization and water and sanitation programs.

Panama: Relations with the Inter-American Development Bank (As of June 3, 2010, in millions of U.S. dollars)

A. Operations

\begin{tabular}{lrrr}
\hline \multicolumn{1}{c}{ Sector } & Commitments & Disbursed & Undisbursed Amounts \\
& & & \\
\hline & & & \\
Agriculture & - & 30.6 & 43.4 \\
Science and Technology & - & 5.3 & 14.4 \\
Urban Dev. And Housing & - & 1.5 & 28.5 \\
Education & - & 45.4 & 12.7 \\
Sanitation & - & 29.2 & 45.8 \\
State Modernization & - & 49.4 & 74.4 \\
Transportation & - & 29.8 & 40.2 \\
Private Sector Development & - & 5.7 & 50.6 \\
Disaster Prevention & - & 49.4 & 74.4 \\
Energy & - & 2.8 & 39.7 \\
Social Investment & - & 27.0 & 33.2 \\
Total & - & 244.0 & 422.5 \\
\hline
\end{tabular}

B. Loan Transactions

\begin{tabular}{|c|c|c|c|c|c|c|c|c|c|c|}
\hline & 2001 & 2002 & 2003 & 2004 & 2005 & 2006 & 2007 & 2008 & 2009 & $2010^{*}$ \\
\hline Disbursements & 61.91 & 72.63 & 99.25 & 37.03 & 80.15 & 139.69 & 74.86 & 126.84 & 216.84 & 114.04 \\
\hline Repayments & $(26.85)$ & $(32.95)$ & $(59.16)$ & (74.43) & $(76.89)$ & $(78.67)$ & $(81.04)$ & $(89.43)$ & $(91.37)$ & $(96.26)$ \\
\hline Net Lending & 35.06 & 39.68 & 40.09 & $(37.41)$ & 3.26 & 61.02 & (6.18) & 37.41 & 125.47 & 17.78 \\
\hline Interests and Charges & $(45.32)$ & $(39.43)$ & $(41.42)$ & $(38.40)$ & $(37.32)$ & $(39.59)$ & $(44.52)$ & $(46.38)$ & $(46.78)$ & $(51.91)$ \\
\hline Subscriptions and Contributions & $(0.50)$ & $(0.40)$ & $(0.30)$ & $(3.60)$ & $(3.40)$ & $(1.70)$ & $(1.60)$ & - & $(3.00)$ & $(0.70)$ \\
\hline Net Transfer & $(10.76)$ & $(0.16)$ & $(1.64)$ & $(79.40)$ & $(37.47)$ & 19.73 & $(52.29)$ & $(8.97)$ & 75.69 & $(34.83)$ \\
\hline
\end{tabular}

2. For 2010, the Bank will work in the preparation of four loans in the areas of urban transportation (US\$600 million), road infrastructure (US\$70 million), water and sanitation (US\$40 million) and education (US\$30 million). 


\section{AnNeX IV-STATISTICAL ISSUES}

3. Progress has been achieved in improving the accuracy, timeliness, and publication of economic statistics. Data provided to the Fund are generally adequate for surveillance. However, there is a need to address methodological weaknesses in foreign trade data and to improve the consistency between the national accounts and the external sector accounts. Panama has participated in the Fund's General Data Dissemination System (GDDS) since December 2000. However, the metadata and plans for improving the statistical system that are posted on the Dissemination Standards Bulletin Board (DSBB) need updating.

\section{Real Sector}

4. National accounts data are released with a lag of approximately three months. The index of monthly economic activity is released with a lag of up to two months. Although the timeliness of real sector data provision has improved, the data are often subject to substantial revisions. The World Bank is supporting a project for changing the base year of the national accounts to 2007, which is scheduled to start in the second half of 2010 .

5. A population census was conducted in May 2010 and preliminary results are expected to be published in the last quarter of 2010.

6. The IMF national accounts technical assistance mission conducted in March 2009 noted the limited coverage of financial activity as well as the overestimation of the deflator used to calculate the financial services output at constant prices. The revised GDP estimates of financial activity, and the related overall GDP revision, was published in October 2009.

7. A new Household Income and Expenditure Survey was conducted during 2007-08, and the National Institute of Statistics and Census is in the process of updating the base, basket, and weights of the CPI.

\section{Government Finances}

8. The Ministry of Finance compiles budget execution data for the central government and data on nonfinancial public sector operations (central government, public enterprises, and agencies) on a cash basis. Monthly and quarterly data have been reported up to December 2009 for the budgetary central government operations (www.mef.gob.pa).

9. Further efforts are needed to improve the quality of fiscal data. Apart from timeliness, data consistency in terms of transfers between public sector units should be improved; and the coverage of the public enterprises should be made universal. Since September 2004, the operational balance of the Panama Canal Authority (PCA) was excluded from the official definition of the nonfinancial public sector used for fiscal policy purposes. Information on the Panama Canal Authority (PCA) is only available in the Annual Report posted on its 
website (www.pancanal.com) on a fiscal year basis. There is a need to ensure a consistent and timely flow of PCA statistics on a calendar year basis. The authorities have received technical assistance from STA to implement the government Finance Statistics Manual 2001 (GFSM 2001) and a FAD fiscal ROSC mission took place in October 2005. In February 2004 a STA mission undertook a comprehensive review of the coverage and methodology of fiscal data. The authorities are preparing to migrate to the GFSM 2001 and are upgrading their technological platform to process data and ensure data consistency between the treasury and the government ministries.

\section{Monetary Accounts}

10. Panama has been publishing financial sector data based on the new standardized report forms (SRFs) for monetary statistics in the IFS Supplement since March 2007 and participates in a regional project for harmonizing monetary and financial statistics in Central America and the Dominican Republic. The aim is to facilitate cross-country comparison and regional analysis. Provision of monthly data by the two public financial institutions, the National Bank of Panama and the Savings Bank (Caja de Ahorros), is regular and prompt. Monthly data on the operations of the domestic and international commercial and savings banks is prepared by the Superintendency of Banks, and posted on its website (www.superbancos.gob.pa) and reported to STA with a lag of one to two months. The stateowned development banks, the Agricultural Development Bank, and the Mortgage Bank are not regulated by the Superintendency of Banks and no data is reported to the Fund.

\section{Balance of Payments}

11. Weaknesses in foreign trade flows data, particularly those involving the Colon Free Zone need to be addressed. Substantial changes in the composition of trade flows over the last decade render the current methodology to estimate volume indices obsolete. Quarterly data is available with a delay of about one quarter, and is subject to revisions thereafter. Revised estimates in key trade and investment data may result in substantial revisions of the current account of the balance of payments. These revisions may reflect improvements in coverage, but they also suggest that there is room for improvement in quality control procedures. Quarterly International Investment Position (IIP) data have been compiled since 2002, and annual data are available since 1998. The most recent balance of payments and IIP data pertain to December 2009. 


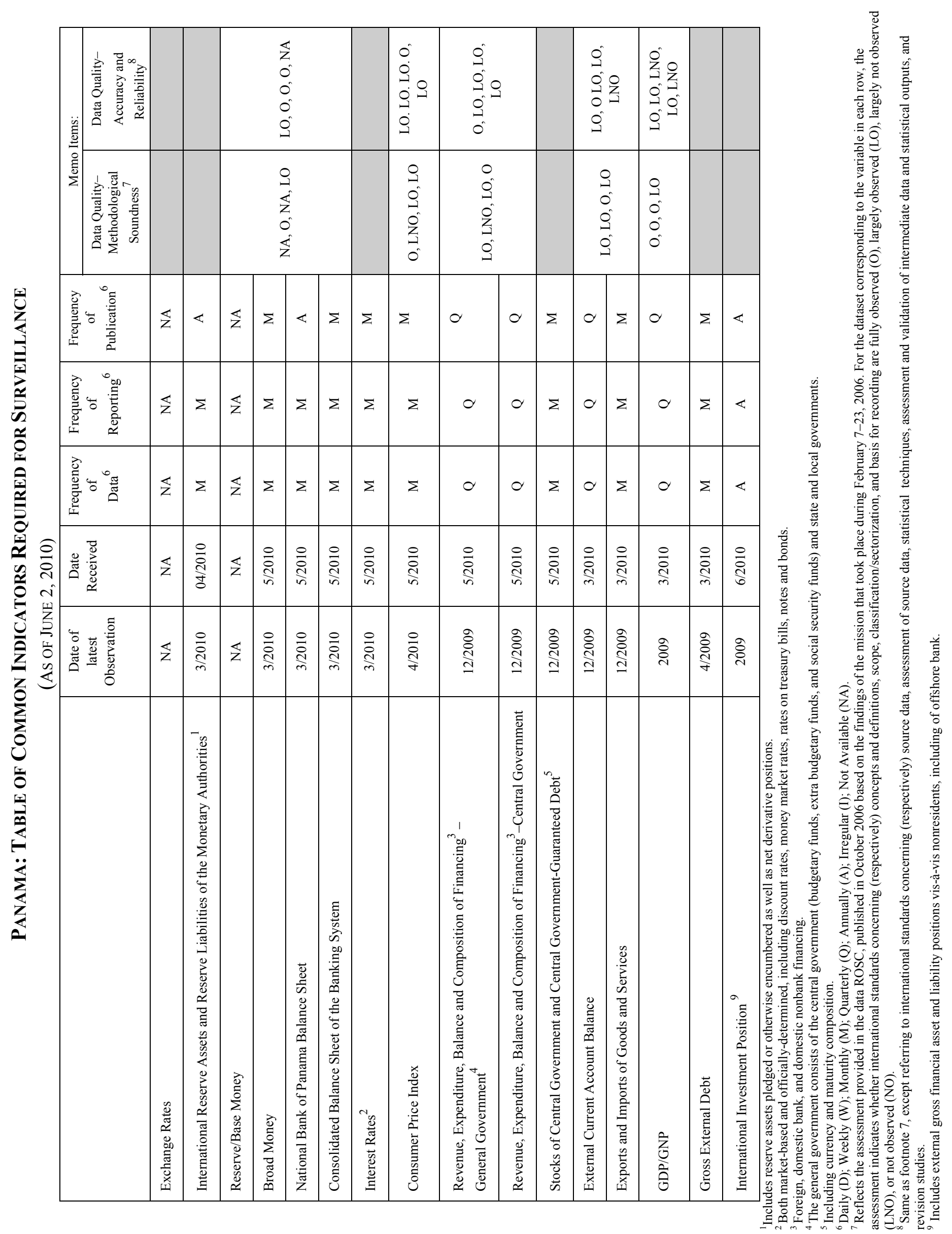


Public Information Notice (PIN) No. 10/109

FOR IMMEDIATE RELEASE

August 3, 2010
International Monetary Fund

$70019^{\text {th }}$ Street, NW

Washington, D. C. 20431 USA

\section{IMF Executive Board Concludes 2010 Article IV Consultation with Panama}

On July 12, 2010, the Executive Board of the International Monetary Fund (IMF) concluded the Article IV consultation with Panama. ${ }^{1}$

\section{Background}

Sound public finances and a strong banking system allowed Panama to face the global financial crisis of 2008 from a strong position. While GDP growth slowed in 2009, it remained positive at 2.5 percent and continued to surpass the region's average. The unwinding of global supply shocks and weaker domestic demand led to a decline in inflation to about 2 percent. Inflation has risen somewhat in 2010, but remains low at about 3 percent (year over year) in May. The external current account improved markedly and was in balance, reflecting lower oil prices and very strong export growth from the Colon Free Zone. The overall fiscal deficit (excluding the Panama Canal Authority, PCA) was 1 percent of GDP in 2009, well below the deficit ceiling in the social and fiscal responsibility law (SFRL) for that year (2.5 percent of GDP).

The banking system remains on a strong footing, helped by effective supervision and a prudent stance by banks. Bank financial soundness indicators are solid, with high levels of capitalization and low non-performing loan rates. Growth of bank credit to the private sector decelerated in 2009, owing to tighter lending standards and weaker private demand. Credit growth, however, started to recover in the first quarter of 2010.

\footnotetext{
${ }^{1}$ Under Article IV of the IMF's Articles of Agreement, the IMF holds bilateral discussions with members, usually every year. A staff team visits the country, collects economic and financial information, and discusses with officials the country's economic developments and policies. On return to headquarters, the staff prepares a report, which forms the basis for discussion by the Executive Board. At the conclusion of the discussion, the Managing Director, as Chairman of the Board, summarizes the views of Executive Directors, and this summary is transmitted to the country's authorities.
} 
The new government has put in place two substantive tax reforms since taking office in July 2009. The reforms, which were approved in September 2009 and March 2010, seek to increase revenues to finance higher capital spending, while improving the efficiency of the tax system. Among other measures, they include broadening of the tax base, changes to dividend taxation, an increase in the value-added tax, lower personal and corporate income tax rates, and elimination of loopholes. The changes are expected to increase revenue by 2.25 percent of GDP on a permanent basis.

Panama's credit rating was raised to investment grade in early 2010 . The upgrade reflected the strengthening of the public finances in recent years, good prospects for further declines in public debt, and a very favorable growth outlook.

GDP growth is projected to pick up to 4.8 percent in 2010, supported by an improved world economy, a large increase in public investment, notably from the Canal expansion project, and a recovery of private demand. Inflation is expected to rise temporarily this year, driven by global trends and higher oil prices, but would remain low. The overall fiscal deficit is projected at 0.9 percent of GDP in 2010, well below the SFRL ceiling (2.5 percent of GDP) and the target envisaged in the budget (1.9 percent of GDP).

\section{Executive Board Assessment}

Executive Directors commended the authorities for their sound policies and appropriate policy response to the global financial crisis, which had helped mitigate the effect of the crisis on the economy and the financial sector. The timely implementation of policy measures, particularly in the fiscal area, contributed to the rapid recovery in economic activity and low unemployment. Directors also welcomed the improvement in Panama's sovereign credit rating to investment grade. They stressed that maintenance of sound policies would provide the basis for continued strong economic growth and further reduction in poverty.

Directors agreed that, in light of the strength of the economic recovery, some withdrawal of fiscal stimulus in 2010 would be appropriate. They welcomed the adoption of a medium-term fiscal framework and the government's ambitious plans for fiscal consolidation over the medium term. Directors noted that the targeted decline in public debt would create additional room for using fiscal policy as a countercyclical tool. They commended the authorities for the adoption of two comprehensive tax reforms during the past year, which would bolster the credibility of the fiscal framework. Directors also supported the authorities' ongoing efforts to strengthen tax administration, and encouraged similar steps in the area of customs.

Directors welcomed the resilience of the banking system to the global financial crisis. To further bolster banking system stability and reduce costs to the economy from high liquidity holdings by banks, they welcomed work toward the establishment of a formal 
safety net, while keeping in mind moral hazard concerns. Directors supported the authorities' plans to introduce risk-based supervision and adopt Basel II regulatory requirements. They also concurred with the initiative to broaden the financial regulation perimeter by bringing nonbank deposit-taking institutions under the umbrella of the Superintendency of Banks.

Directors welcomed the progress made toward removal from the Organization for Economic Cooperation and Development (OECD) gray list of tax havens. They encouraged the completion of remaining agreements and adoption of necessary legal changes.

Public Information Notices (PINs) form part of the IMF's efforts to promote transparency of the IMF's views and analysis of economic developments and policies. With the consent of the country (or countries) concerned, PINs are issued after Executive Board discussions of Article IV consultations with member countries, of its surveillance of developments at the regional level, of post-program monitoring, and of ex post assessments of member countries with longer-term program engagements. PINs are also issued after Executive Board discussions of general policy matters, unless otherwise decided by the Executive Board in a particular case. 
Panama: Selected Economic Indicators

\begin{tabular}{|c|c|c|c|c|c|c|}
\hline & 2005 & 2006 & 2007 & 2008 & 2009 & $\begin{array}{l}\text { Proj. } \\
2010\end{array}$ \\
\hline \multicolumn{7}{|c|}{ (Percent change) } \\
\hline \multicolumn{7}{|l|}{ Production and prices } \\
\hline Real GDP (1996 prices) & 7.2 & 8.5 & 12.1 & 10.7 & 2.4 & 4.8 \\
\hline Consumer price index (average) & 2.9 & 2.5 & 4.2 & 8.8 & 2.4 & 3.3 \\
\hline Consumer price index (end of year) & 3.4 & 2.2 & 6.4 & 6.8 & 1.9 & 3.0 \\
\hline \multicolumn{7}{|l|}{ Financial sector } \\
\hline Private sector credit & 13.3 & 12.9 & 18.2 & 14.6 & 0.8 & 9.1 \\
\hline Broad money & 8.5 & 21.5 & 15.9 & 18.5 & 13.4 & 10.0 \\
\hline Average deposit rate (1 year) & 3.2 & 5.1 & 4.6 & 3.5 & 3.6 & $\ldots$ \\
\hline Average lending rate (1 year) & 8.2 & 8.6 & 9.0 & 8.5 & 7.5 & .. \\
\hline \multicolumn{7}{|l|}{ External trade 1/ } \\
\hline Merchandise exports & 11.9 & 14.3 & 11.7 & 5.2 & -27.1 & 19.8 \\
\hline Merchandise imports & 14.3 & 18.2 & 40.7 & 18.9 & -15.2 & 22.7 \\
\hline \multicolumn{7}{|c|}{ (Percent of GDP) } \\
\hline \multicolumn{7}{|l|}{ Saving-investment balance } \\
\hline Gross domestic investment & 18.4 & 19.5 & 24.1 & 27.4 & 24.8 & 26.7 \\
\hline Gross national saving & 13.4 & 16.3 & 16.9 & 15.8 & 24.8 & 18.7 \\
\hline \multicolumn{7}{|l|}{ Nonfinancial public sector } \\
\hline Revenue and grants & 24.3 & 26.8 & 29.7 & 29.2 & 27.4 & 27.8 \\
\hline Expenditure & 25.9 & 25.6 & 25.0 & 26.7 & 27.9 & 29.8 \\
\hline Overall balance & -1.6 & 1.2 & 4.8 & 2.5 & -0.5 & -2.0 \\
\hline Overall balance, excluding ACP 2/ & -2.6 & 0.5 & 3.4 & 0.4 & -1.0 & -0.9 \\
\hline \multicolumn{7}{|l|}{ Total public debt } \\
\hline Total debt & 58.7 & 52.6 & 45.6 & 38.8 & 39.4 & 40.4 \\
\hline o/w external debt & 45.5 & 40.5 & 37.4 & 32.7 & 36.5 & 38.5 \\
\hline \multicolumn{7}{|l|}{ External sector } \\
\hline Current account & -4.9 & -3.1 & -7.2 & -11.6 & 0.0 & -7.9 \\
\hline Net exports from Colon Free Zone & 3.7 & 3.4 & 2.3 & 0.0 & 8.2 & 3.3 \\
\hline Net oil imports & 3.4 & 3.1 & 4.4 & 5.9 & 3.6 & 4.4 \\
\hline Foreign direct investment & 6.2 & 14.6 & 9.6 & 10.4 & 7.2 & 7.7 \\
\hline \multicolumn{7}{|l|}{ Memorandum items: } \\
\hline GDP (in millions of US\$) & 15,465 & 17,137 & 19,794 & 23,184 & 24,711 & 26,689 \\
\hline
\end{tabular}

Sources: Comptroller General; Superintendency of Banks; and IMF staff estimates.

1/ Excludes the Colon Free Zone.

2/ Panama Canal Authority (ACP). 


\section{Statement by Paulo Nogueira Batista, Executive Director for Panama and Alfredo Maciá, Advisor \\ July 12, 2010}

1. On behalf of the Panamanian authorities, we thank Mr. Abrego and his team for the constructive and candid dialogue. We welcome the staff's balanced and informative set of documents.

2. Since the beginning of President Martinelli's administration on July $1^{\text {st }}, 2009$, new economic and social reforms were set in motion in response to the world economic crisis and the still uncertain strength of the recovery of Panama's main trading partners. The government saw a need to continue to boost economic activity for the rest of 2009 and beyond. Several measures were taken to strengthen revenues, allowing an expansion of infrastructure investments and of social programs to protect the most vulnerable. The new authorities jump-started fiscal revenue reforms, launched a tax moratorium to collect tax arrears, and accelerated the start of new public investment projects. Also, the authorities rolled-out a challenging economic and social infrastructure investment program of over US\$13 billion set out in the 2010-14 Strategic Development Plan (SDP). In mid-July 2009, the Panama Canal Authority (PCA) awarded the locks contract of US\$3.1 billion. Moreover, the government implemented reforms to make the labor code less rigid, streamline the public contract-law and improve the judicial system, among others. The authorities foresee additional reforms to strengthen the overall efficiency of the economy and of the public sector.

3. The world economic slowdown affected most sectors of the economy in 2009. After exceeding 10 percent in 2008, GDP growth slowed to 2.4 percent in 2009. Despite this sharp slowdown, Panama's growth continued to exceed the Latin American average, thanks to domestic demand, FDI flows, and the ongoing Panama Canal expansion. Unemployment increased by only1 percentage point to 6.6 percent at the end of 2009 .

4. As noted by the staff, economic activity rebounded strongly in the last quarter of 2009 and into the first quarter of 2010, when GDP grew 4.9 percent compared to the same period of 2009. In that quarter, production increased considerably in sectors such as mining, construction, commerce, energy generation, telecommunications, port activities, and tourism. The government expects growth of 5 percent of GDP in 2010 and of more than 6 percent in the medium term.

5. In 2009, inflation declined rapidly on account of lower international commodity prices and the slowdown in economic activity. The Ministry of Economics and Finance (MEF) projects a slightly higher inflation of 3 percent for end-2010, as oil and commodity prices rebound due to better global economic prospects.

6. The current account improved markedly in 2009, moving to a balanced position from a deficit of 11.6 percent of GDP in 2008. This result reflects lower commodities import prices, a large increase in net exports from the Colon Free Zone (ZLC), and a 
decrease in the value of imports due to the sharp slowdown of the economy. However, the current account deficit is estimated by staff to rise to about 8 percent of GDP this year and in 2001. This sharp increase is largely associated with the Panama Canal expansion, the large public infrastructure program of the SDP, and continued FDI inflows, all of which have a high import-content. FDIs and other capital inflows are expected to fully cover the deficits on current account.

7. Against the backdrop of the global economic crisis and the domestic economic slowdown during 2009, the outgoing administration, in agreement with the representatives of the elected government, augmented the social and fiscal responsibility law's (SFRL) deficit ceiling from 1 to 2.5 percent of GDP for 2009. In spite of the available fiscal space, the Martinelli administration proceeded with caution. The new government tried to balance counter-cyclical fiscal policy with control of the deficit. To this effect, the MEF carried out a revenue reform barely three months after inauguration; another reform followed in early 2010. Also, the already-mentioned tax moratorium was set in place with positive effects on revenue collection. Furthermore, a clamp-down on expenditures was enforced. These measures were crucial to keeping the nonfinancial public sector's deficit (excluding the PCA) at only 1 percent of GDP in 2009, well below the 2.5 percent deficit ceiling allowed by the revised SFRL.

8. The two recent fiscal reforms widened the tax base, increased real state and VAT taxes, and targeted sectors that had been making relatively modest contributions to tax revenue such as ports, banks, insurance companies, the ZLC, and casinos. These reforms are expected to generate over 2.5 percent of GDP in additional tax revenues. As a result, tax revenue in 2010 may reach 13 percent of GDP compared to 10.6 percent of GDP in 2007 , enhancing the prospects for higher levels of capital spending. The 2010 budget targets a deficit of 1.9 percent of GDP, which is slightly lower than the 2 percent ceiling of the SFRL. Staff believes that the government will again over perform and that the deficit will be 0.9 percent of GDP this year.

9. Fiscal consolidation remains vital to the government's debt reduction strategy, which aims to bring public debt down to 35.8 percent of GDP by 2014. Despite the global crisis, by end-2009 public debt stood at 45 percent of GDP unchanged from end-2008, according to figures published by the MEF. Panama's public debt ratio in 2010 is expected to be slightly lower than in 2009 , falling to 44 percent of GDP.

10. The government has set in motion new social programs and expanded existing programs. It has also pursued rigid controls against fraud and enhanced accountability measures in the implementation of these programs. Income redistribution is a major goal. One of the new initiatives is the " 100 at 70 " program, which provides a monthly cashtransfer of US\$100 to people above 70 years of age that are not protected by the social security system and have no pensions and no access to health care. Over 70,000 elderly people are covered by this program that has a US\$84 million budget for 2010. Also, a US $\$ 5,000$ bonus is now being awarded for the first-time purchase of houses not exceeding US\$30,000 in value. The bonus is provided to banks in order to permit a reduction of the corresponding mortgage. To qualify, the buyer's income must not exceed US\$800 a month. Also new is the US\$20 monthly assistance to rural students nationwide 
with a view to reducing drop-out rates. Furthermore, the government has maintained all the previous social initiatives such as preferential interest rates on low-income housing and agricultural loans, subsidized cooking gas, and the cash-transfers for extremely poor families. In addition, the administration increased the minimum-wage, wages in the health and security sectors, as well as the salaries of low-income public employees. It has also reduced income-tax rates for lower incomes.

11. Panama expects a high level of public and private investment, including a sustained flow of FDIs in 2010 and beyond. The most relevant ongoing public projects are the Panama Canal expansion (a US\$5.3 billion project), the airport and the inner-city highway expansion, the oil pipeline and storage facilities, an upgrade of the PanamaBay's sewage and drainage systems, and the metropolitan bus project for public transportation. In addition, the SDP investments plan includes the Curundú low-income housing project, the construction of a series of new government buildings (Centro Gubernamental), five state-of-the-art hospitals and ten primary-attention health centers, a new penitentiary complex, a light rail metro system, a convention center, and the expansion of the high-speed highway system. Some of these projects have already been tendered while others are in the public bid process or at a design stage. The 2010 public investment budget stands at US $\$ 2.5$ billion. The authorities aim to attain an 80 percent execution rate in 2010 compared to 66 percent in 2009. Private investments are expected to increase in various sectors. There are over 19 ongoing energy projects, including hydro, thermo, and aeolic. Also, over 20 hotels of local and international chains, port facilities, and commercial building are under construction. Public private partnership legislation is being prepared and will open new opportunities for private sector participation in large public investment projects.

12. The authorities have been actively promoting Panama as a safe investment destination. In this regard, we note the President's personal efforts in the international arena, the progress in double taxation treaties to eliminate Panama from the OECD's grey list, and the newly negotiated free trade agreement with Canada. These agreements are expected to enhance FDI prospects in Panama.

13. The banking sector remained solid in 2009 , partly because of high liquidity and strong supervision. The capital adequacy ratio (CAR) for the banking sector reached 16.4 percent in 2009 compared to 14.8 percent in 2008. Statutory CAR is 8 percent. Nonperforming loans (NPLs) actually decreased during 2009 to 1.4 percent of total loans from 1.6 percent in the previous year, as bankers tightened lending requirements and pursued safety in higher liquidity rather than in profitability. Accordingly, return on assets (ROA) diminished in 2009 to 1.4 percent from 2.2 percent in 2008.

14. The first quarter of 2010 already shows a trend of increased credit. Mortgages are particularly strong compared to the same period in 2009. Also, net earnings in the system are up 20 percent. The results of the staff's stress testing of the banking sector indicate that capital levels in the system would remain adequate under sizeable shocks to economic activity and the quality of assets. 
15. Only a few days after inauguration, the government began to address the issue of the OECD grey list by reactivating, in late July 2009, the Presidential Commission that deals with international financial services. The Minister of Finance has been leading the efforts to conclude at least 12 double-taxation treaties by the end of 2010, as agreed with OECD. This will allow the removal of Panama from the OECD's so-called grey list. As of today, 9 of the 12 required agreements have been negotiated. All these treaties require congressional approval. Panama is determined to overperform the established OECD goal for 2010 and remains committed to eliminating any doubts about the rules governing the country's banking system.

16. The recent investment grade assessments of the country's sovereign credit by Fitch Ratings, Standard and Poor's, and Moody's open new prospects for stronger growth and investments in Panama. One of the staff's Selected Issues papers highlights the benefits from the new ratings. These include lower borrowing costs, new funding sources for domestic corporates and the public sector, and new portfolio options for international investors. 